University of Nebraska - Lincoln

DigitalCommons@University of Nebraska - Lincoln

1962

\title{
Floods in Nebraska on Small Drainage Areas Magnitude and Frequency
}

Emil W. Beckman

Norman E. Hutchison

Follow this and additional works at: https://digitalcommons.unl.edu/usgspubs

Beckman, Emil W. and Hutchison, Norman E., "Floods in Nebraska on Small Drainage Areas Magnitude and Frequency" (1962). Publications of the US Geological Survey. 96.

https://digitalcommons.unl.edu/usgspubs/96

This Article is brought to you for free and open access by the US Geological Survey at DigitalCommons@University of Nebraska - Lincoln. It has been accepted for inclusion in Publications of the US Geological Survey by an authorized administrator of DigitalCommons@University of Nebraska - Lincoln. 


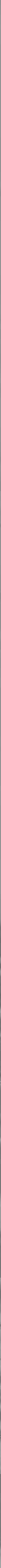




\section{Floods in Nebraska on Small Drainage Areas, Magnitude and Frequency}

By Emil W. Beckman and Norman E. Hutchison

Prepared in cooperation with the Nebraska Department of Roads<smiles>CC1(C)CCCC1</smiles>

Geological Survey Circular 458 
United States Department of the Interior STEWART L. UDALL, SBCRBTARY

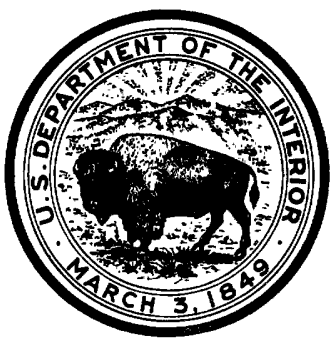

Geological Survey

THOMAS B. NOLAN, Director<smiles>[V]</smiles>

Free on application to the U.S. Geological Survey, Washington 25, D. C. 


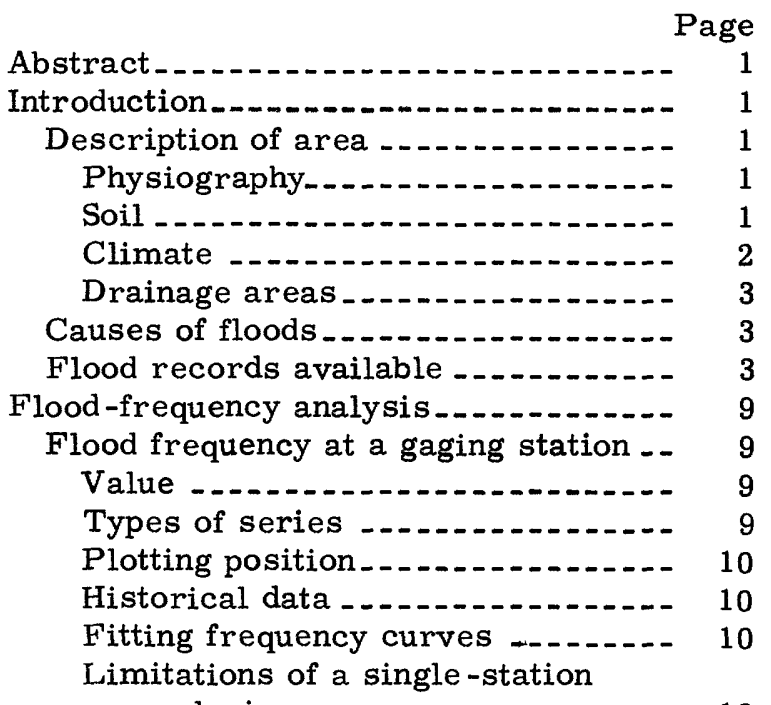
analysis _................. 10

Flood-frequency analysis-Cont.

Page

Regional flood-frequency analysis - - 11

Base period .................. 11

Definition of mean annual flood -.- 11

Homogeneity of records........ 12

Composite frequency curves...-.- 12

Relations of mean annual flood.... 12

Hydrologic areas............... 14

Application of regional flood-frequency

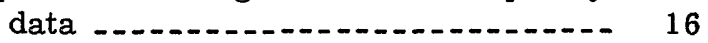

Tributary areas of natural runoff -.. 16

Stage of flood discharge........... 16

Maximum known floods_._._._._._. 17

Summary _..._._._._._._._._. 32

Selected references _..._......... 32

\section{ILLUSTRATIONS}

Pigure 1. Generaliged

Figure 1. Generalized areas of soil sources in Nebraska.

2. Map of Nebraska showing location of gaging stations used in flood-frequency analysis _.

3. Frequency of annual floods, Plum Creek near Smithfield, Nebr.

4. Map of Nebraska showing flood-frequency regions and hydrologic areas _..... 12

5. Composite frequency curves of annual floods, regions A and B, period 1947-59 - 13

6. Variation of mean annual flood with contributing drainage area in hydrologic areas 1-10 10.

7. Relation of maximum discharge to 10 and 25 -year floods, region $A$, areas 1 and 2 ...........

8. Relation of maximum discharge to 10 and 25 -year floods, region $A$, areas

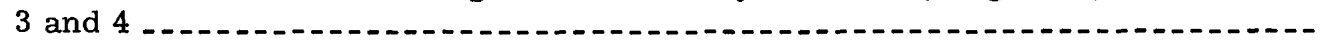

9. Relation of maximum discharge to 10 and 25 -year floods, region $A$, areas 5 and 6 .

10. Relation of maximum discharge to 10 and 25 -year floods, region $\mathrm{A}$, area 7 .

11. Relation of maximum discharge to 10 and 25 -year floods, region $B$, areas 8,9 , and 10

\section{TABLES}

Table 1. Page

1. Period of record of annual peaks at gaging stations

2. Maximum stages and discharges at gaging stations .

3. Unusual peak discharges at miscellaneous sites and at short-term gaging stations with contributing drainage areas of 300 square miles or less _. 


\title{
Floods in Nebraska on Small Drainage Areas, Magnitude and Frequency
}

\author{
By Emil W. Beckman and Norman E. Hutchison
}

\begin{abstract}
Flood hazard information is needed for small streams as well as for large ones. This report explains methods of defining the magnitude and frequency of floods in Nebraska on uncontrolled and unregulated streams which have about 300 square miles or less of drainage area contributing to surface runoff. Composite frequency curves defined for two flood regions express a ratio of floods with recurrence intervals ranging from 1.1 to 25 years to the mean annual flood. Curves for 10 hydrologic areas were defined to show the relation of the mean annual flood to the contributing drainage area. A flood-frequency curve can be drawn from these two sets of curves for any site in the State with in the range of drainage area and recurrence interval that is defined by the base data and not materially affected by the works of man. The two sets of curves are based on all available pertinent data from records of 5 or more years' duration.
\end{abstract}

This report includes a tabulation of maximum flood peaks at gaging stations used and at a number of miscellaneous sites which have less than 300 square miles of contributing drainage area.

\section{INTRODUCTION}

When loss of life is not a factor, it is generally not economically sound to design structures in or across streams for the maximum flood that may occur. Economic considerations will dictate the choice of a design frequency. An evaluation of these economic factors is beyond the scope of this report. It should be noted that the recurrence interval of a flood does not imply any regularity of occurrence. For an example, at any site, two 25-year floods may occur in consecutive weeks or such a flood may not occur in a period of 50 years.

The purpose of this report is to describe methods by which the magnitude and frequency of floods may be determined for most sites in Nebraska for which the drainage area is less than 300 square miles. The report was prepared in the Lincoln office of the U.S.
Geological Survey, under the direction of Floyd F. LeFever, district engineer, Surface Water Branch, in cooperation with the $\mathrm{Ne}$ braska Department of Roads. Financial as sistance in the preparation of the report was given by the Bureau of Public Roads.

\section{DESCRIPTION OF AREA}

\section{PHYSIOGRAPHY}

Nebraska has an expansive, gently rolling to rough topography, broken in places by low hills, a few isolated buttes, mesas, ravines, and several relatively shallow, major streams which flow in an easterly direction.

The altitude of the State ranges from 835 feet at the extreme southeast corner to a maximum of 5,340 feet at the western border. The land surface slopes rather consistently to the southeast with an average decline of about 9 feet per mile.

The small streams of Nebraska have a wide variation in slope depending on the topography of their drainage basins. The average fall for individual streams used in this report ranges from about 6 to about 110 feet per mile. The major streams fall from 4 to 8 feet per mile.

SOIL

Most of the soil mantle of Nebraska originated from four major sources. The general location of these soils is shown on figure 1, which is based on reports by the Nebraska State Planning Board (1941), by Condra (1920), and by Jenkins and others (1946), and was used by Furness (1955). 


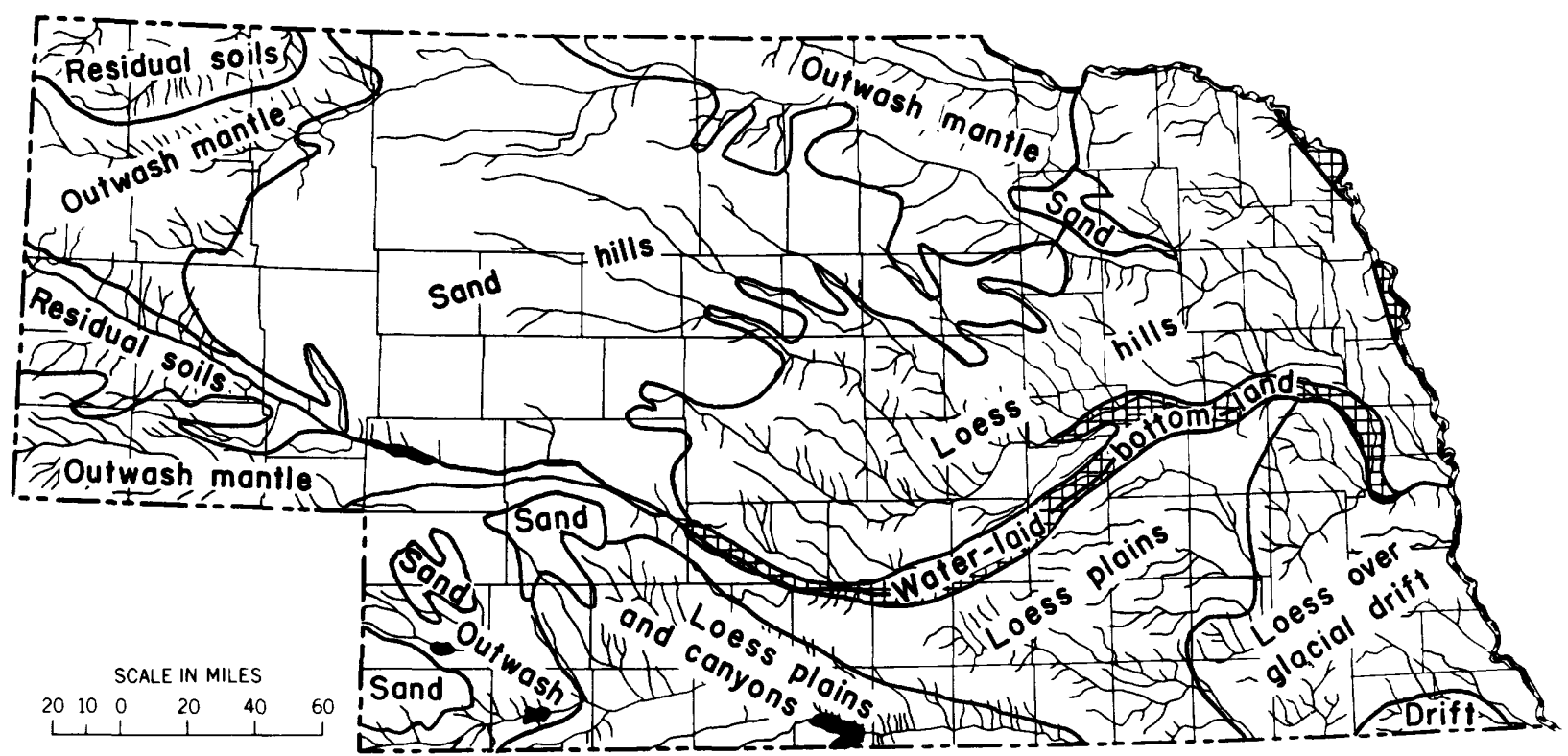

Figure 1. -Generalized areas of soil sources in Nebraska.

Loess silt is the predominant mantle of Nebraska. It is wind transported from both glacial deposits and mountain outwash and is quite uniform in texture but decreases in grain size toward the southeast. It erodes readily when on a steep gradient and usually with a vertical cleavage line. Except for scattered land-locked areas in the headwaters of streams draining relatively level areas of the south-central plains, the drainage patterns are connected and runoff is prompt.

The Sand Hill region, second in areal extent of the four major soil areas, is composed mostly of porous dune sand formed from the weathering and reworking of sandy bedrock and early water and glacial deposits of sand and gravel. Except in the immediate vicinity of the few primary channels, there is no drainage pattern or surface connections to the streams. Rainfall readily reaches the high ground-water table and forms numerous lakes and marshes. Sand Hill streams have a fairly uniform flow which originates from the ground-water table. Flood runoff is minor and comes primarily from the narrow strips of land immediately adjoining the streams.

The outwash mantle from the mountains to the west and northwest is found in several areas along the western and northern parts of the State. The original high-plains surface remains as a variety of topographic forms ranging from comparatively smooth to rolling, as deeply eroded canyons, and as rough broken areas. The soil varies widely in texture. The drainage pattern is generally well defined and runoff is prompt although the slope of each drainage basin is an influencing factor.

Residual soils, the least in areal extent formed in place from sedimentary rocks and are found primarily in several smaller areas of western Nebraska. The ground surface varies from nearly level to undulating, rolling, rough and mountainous. Sedimentary rocks are exposed in the rough badlands. The soil texture also has a wide range in the residual soil areas. The drainage pattern is weil defined and runoff is quite prompt.

Water-laid bottom land and areas of glacial drift are exposed to a very limited extent in the State.

\section{CLIMATE}

The climate of Nebraska is typical of large interior continental areas in the middle latitude; it is characterized by light average annual precipitation, a great range of precipitation from season to season and year to year, and frequent and abrupt changes in temperature and other weather conditions.

The average annual rainfall shows a gradual progressive increase from 14 inches in the extreme western part of the State to 34 
inches in the southeastern corner. About 75 percent of the annual precipitation falls during the six-month period April through September and about 42 percent of the annual precipitation falls in May, June, and July. A large part of the summer rainfall occurs during thunderstorms and generally falls at intense rates in short periods of time.

\section{DRAINAGE AREAS}

The total drainage area of streams in a major part of Nebraska does not contribute to the surface runoff; therefore, it is necessary to determine both the total drainage area and the area which contributes to the stream by surface runoff. Both total and contributing drainage areas are shown for the stations used; however, owing to the lack of complete coverage of good topographic maps of the State, some of the drainage area figures are qualified as approximate. Some of the small drainage areas were determined from aerialsurvey photographs obtained from the U.S. Department of Agriculture, Commodity Stabilization Service.

Nebraska is completely mapped by 1:250,000-scale maps of either 50-foot or 100 -foot contour intervals. The scale and contour intervals do not permit reliable determination of drainage areas, especially for smaller, fairly level areas or, differentiation between contributing and noncontributing drainage areas.

Topographic maps, in scales varying from $1: 24,000$ to $1: 125,000$ and with contour intervals varying from 5 to 20 feet, have been published for about two-thirds of the State.

\section{CAUSES OF FLOODS}

In Nebraska the annual floods on drainage areas of less than 300 square miles generally occur during the months April through September. There are some spring breakup floods; they occur most frequently in the Sand Hill region where there is a relatively limited range in discharge.

Rainfall is the primary cause of floods. Much of the rainfall results from thunder storms and ranges widely in amount, intensity, and distribution, so that the relation of the actual amount of rainfall to the flood peak cannot be correlated. Besides the stream basins physiography which is fairly stable, the following conditions also influence the size of floods: (1) antecedent conditions, (2) direction of the storm, (3) variation of soil infiltration rate, and (4) land use and vegetal cover.

\section{FLOOD RECORDS AVAILABLE}

Records for 5 or more years in length of the annual floods not materially affected by regulation and diversion are available for 136 stations in Nebraska which have 300 square miles or less in contributing drainage area. In addition, six stations which have more than 300 square miles of contributing drainage area are included because of their strategic location. These six stations are: White River at Crawford, Ponca Creek at Anoka, Plum Creek near Meadville, Long Pine Creek near Riverview, Bazile Creek near Niobrara and Wood River near Riverdale. Table 1 gives a list, in the downstream order, of the stations used, their drainage area size, and a graphical illustration of the length of record of annual peaks. Of the total of 142 stations, 83 are crest-stage gages, most of which are operated in cooperation with the Nebraska Department of Roads to define the annual peak discharge. Figure 2 shows the location of the 142 stations. The symbols on the map identify the type of station and the number shown on the map corresponds to the number preceding the station name in table 1. 


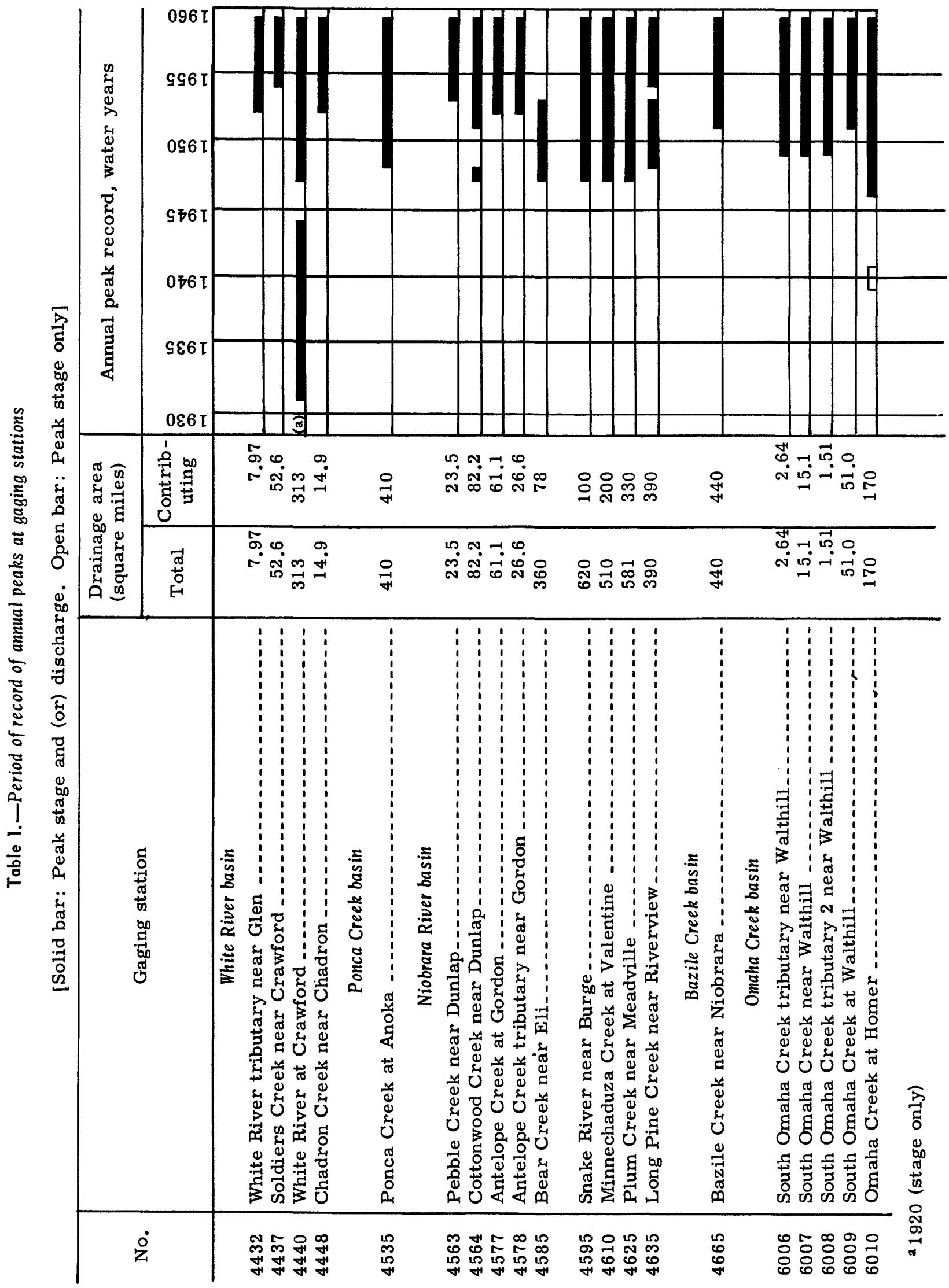




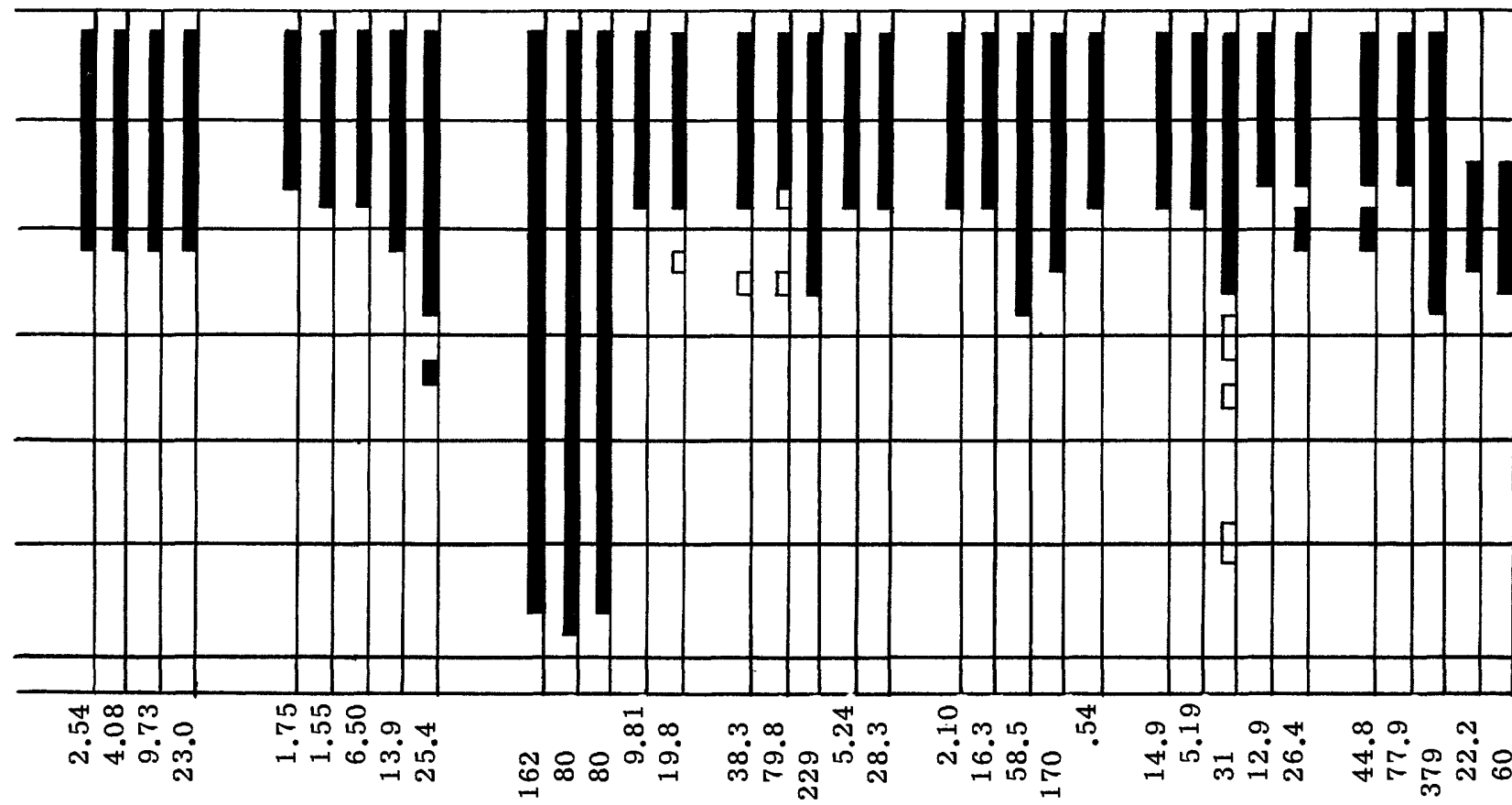

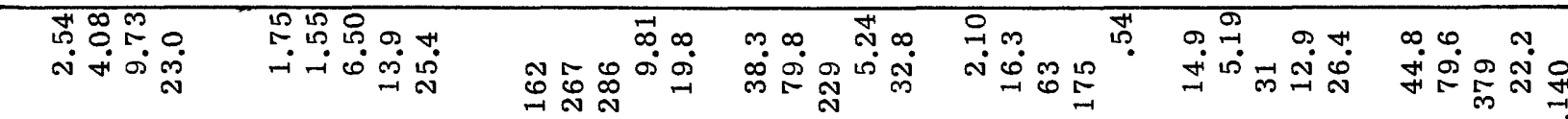

$\equiv$ त्र $\mathrm{E}$

氙嵒

สี むี

๘

齐 吾

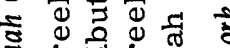

हैं

둥 동 동

घ छ छ $\mathrm{E}$

可可政

(0)

동

仓ั

สี สี

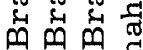

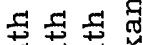

员饮苋

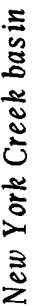

1.

:

1 告嵒

\&

प्षे की त

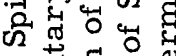

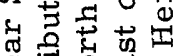

过

牙 齐

\&

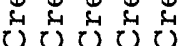

$x$ 선

兵出出出

가서

3333

岩艺艺

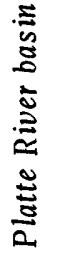

11 व

$\approx$ 1 $1:$

ช 1 क्ष

क

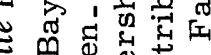

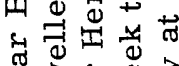

约

⿶凵先U

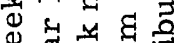

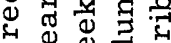

U巳

उ

ญ

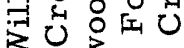

उ运

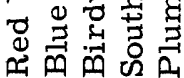

द

ฮี 1 :

क '

斦

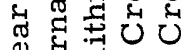

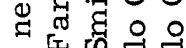

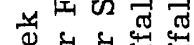

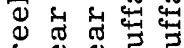

Uั

द्व 헝 뎡

马 叉

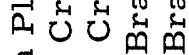

뎐 द्व

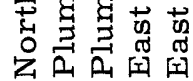

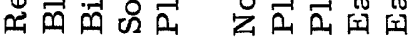

$\sim \infty 0$

동ㅇㅇㅇ

됴용 我

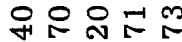
क⿻

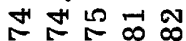
厄

\section{㺃}

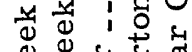

艺过染昰

०คठ

त्र

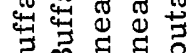

ตि

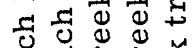

용혀

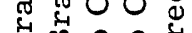

ติ

苑范哥

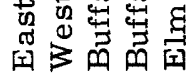

'

के

15

1

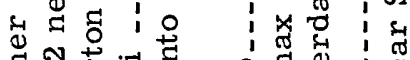

壳

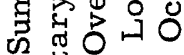

당 क्ष

Ð

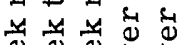

ه \& $\$$

¿

UUU

द्व द्व :

동: 머영 ठै कै $\longrightarrow \circlearrowright$ ता द्व एँ

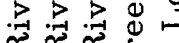

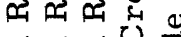
ช 方苔空

ำ 00000
ชั ตุำ

공영응요

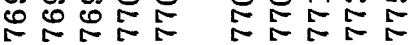




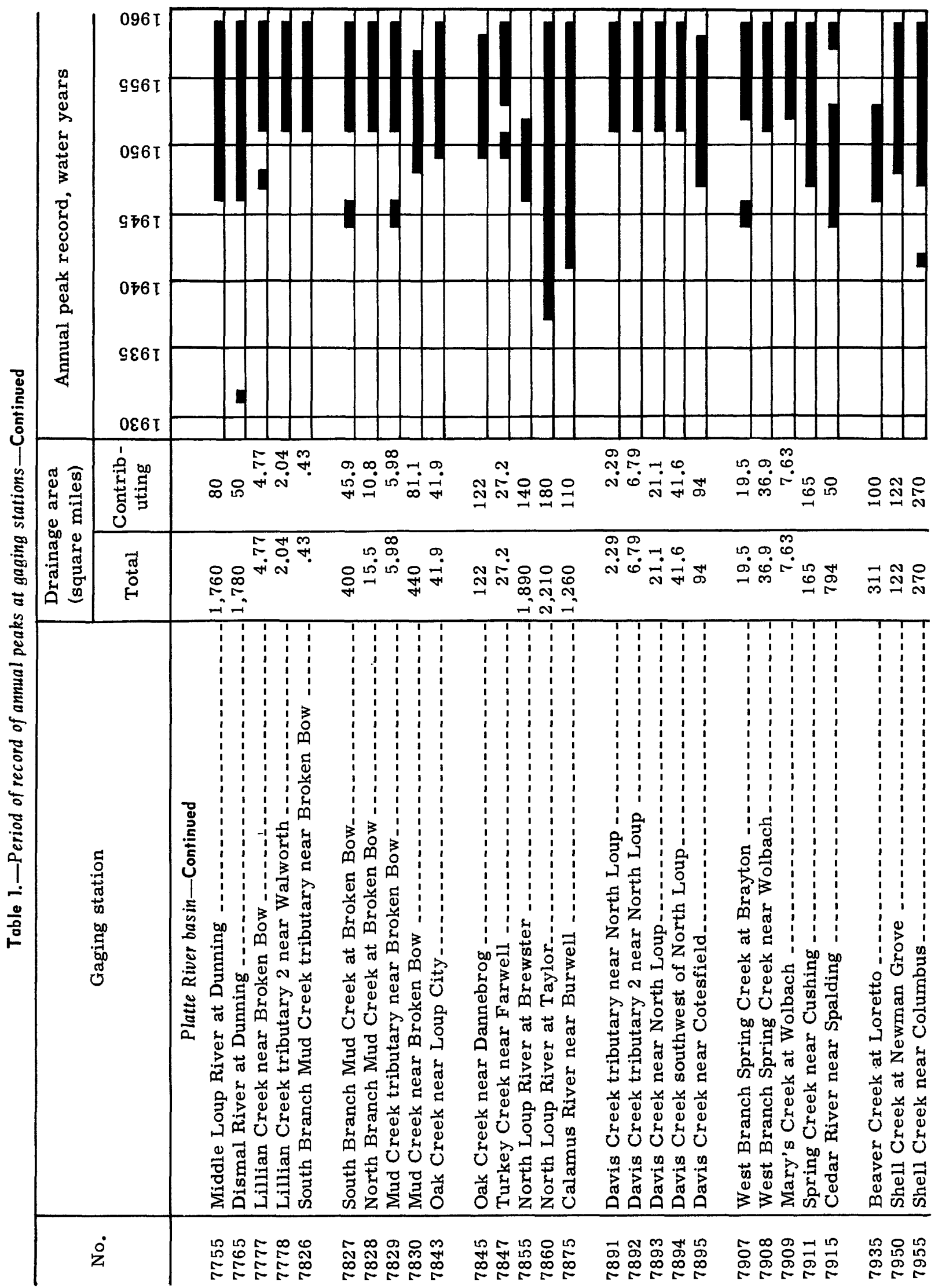




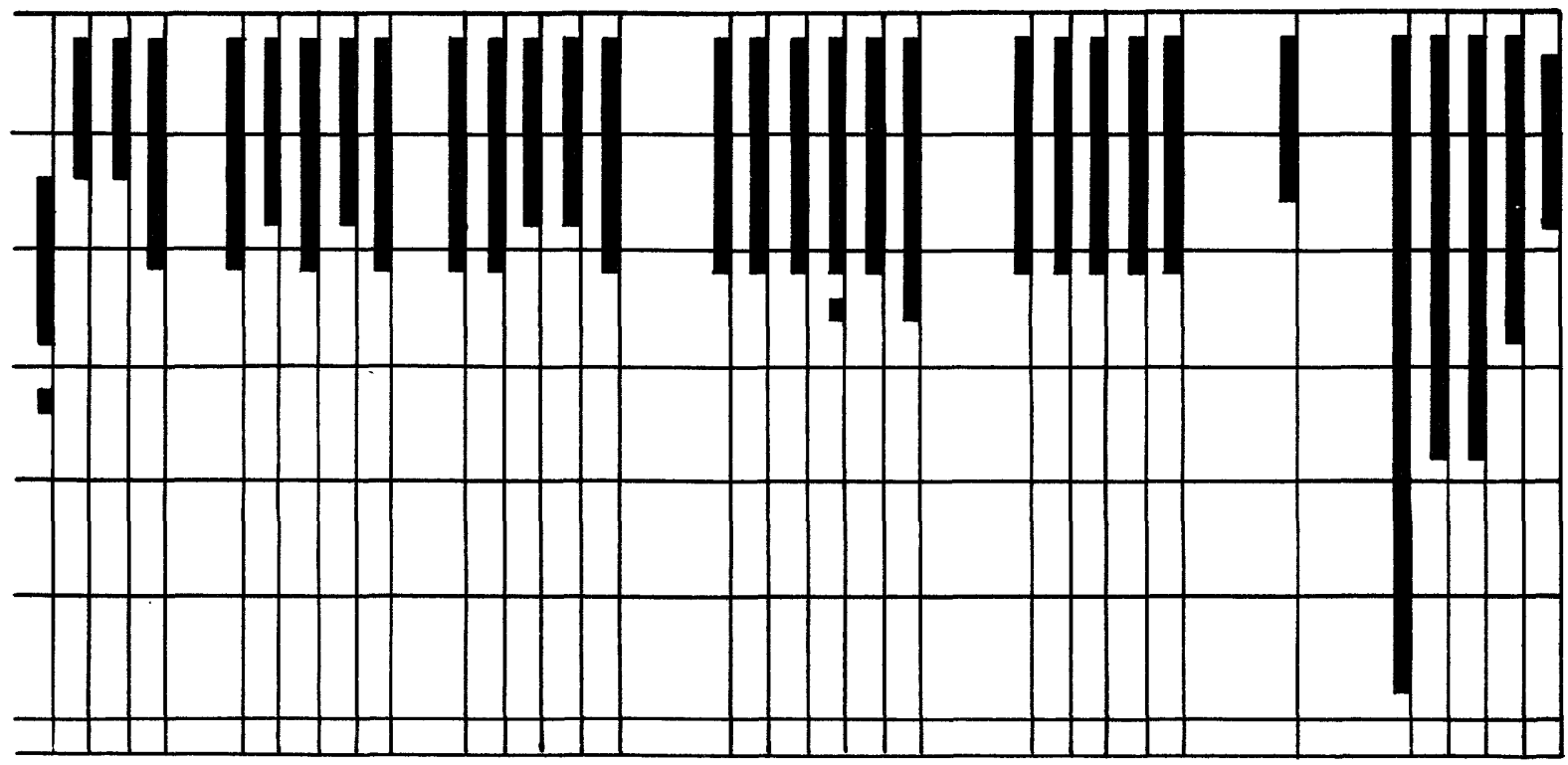

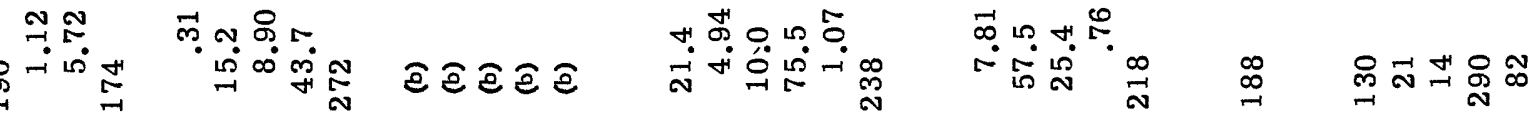

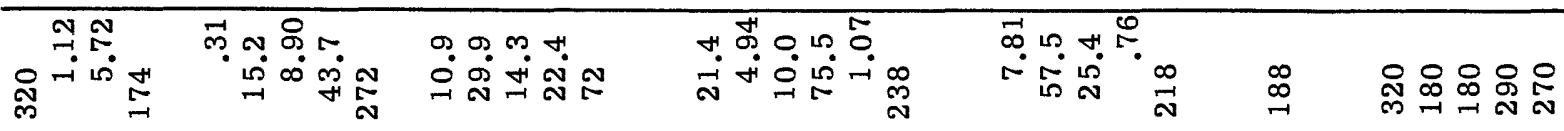

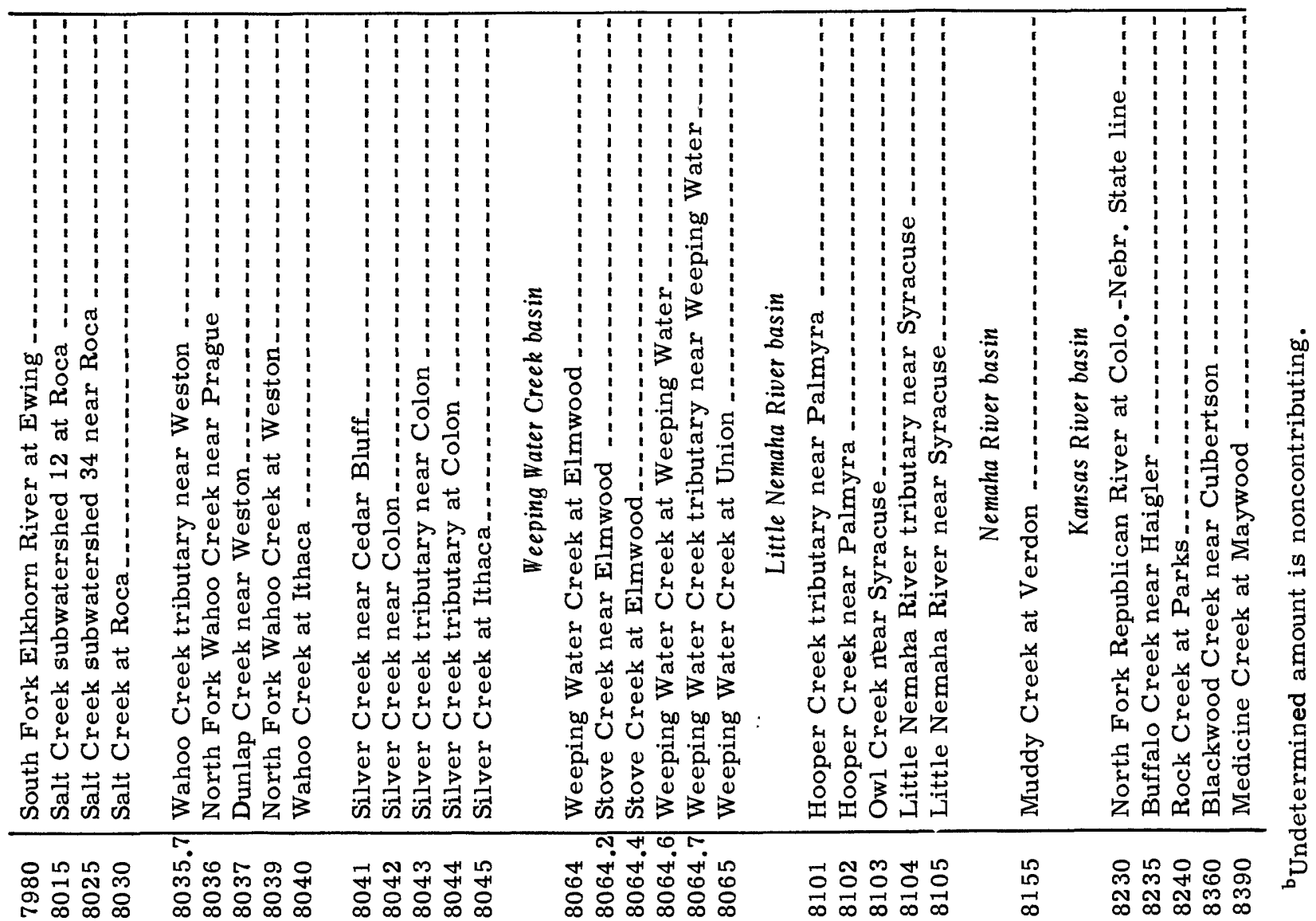




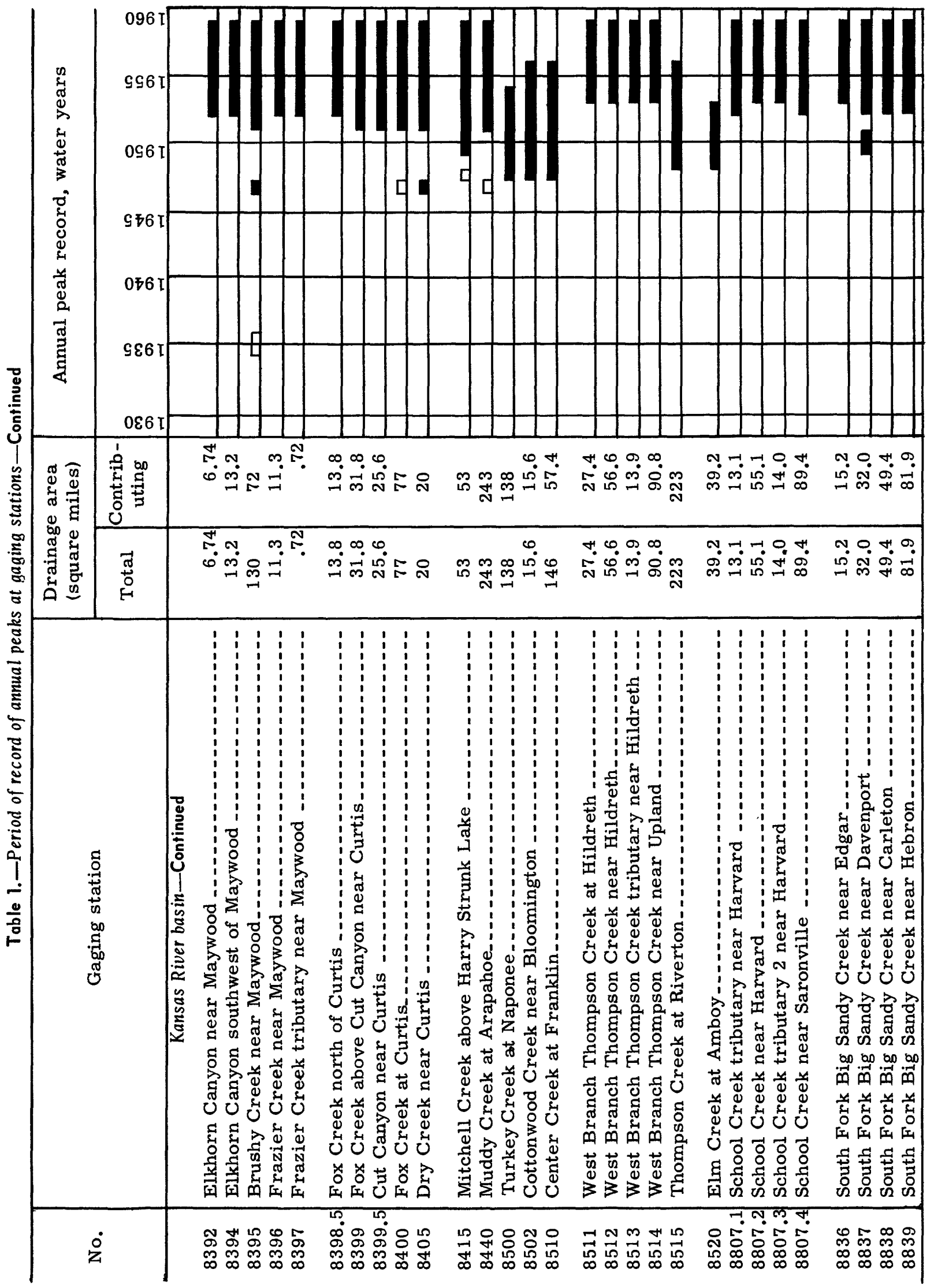




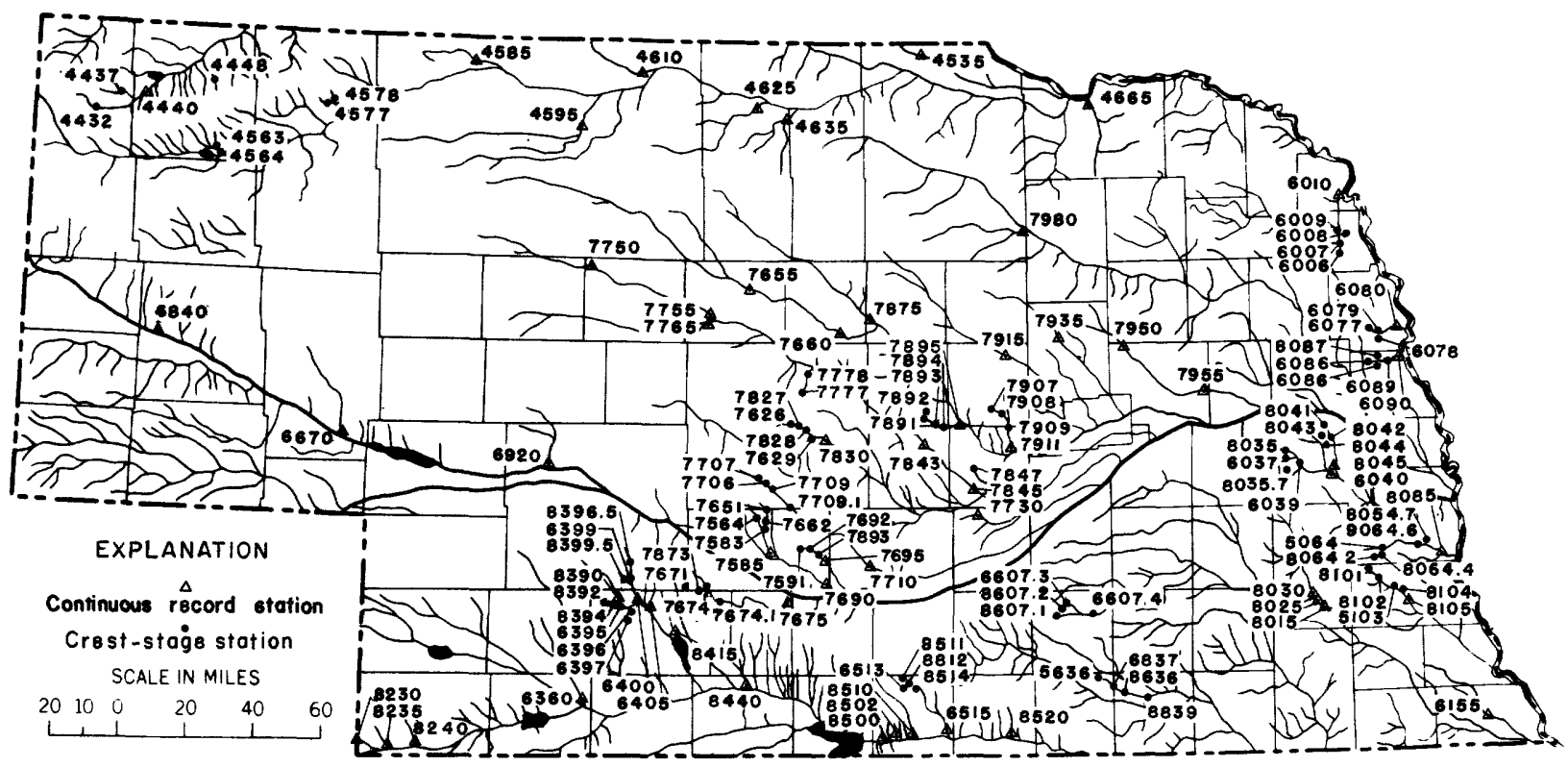

Figure 2. -Map of Nebraska showing location of gaging stations used in flood-frequency analysis.

\section{FLOOD-FREQUENCY ANALYSIS}

\section{FLOOD FREQUENCY AT A GAGING STATION}

\section{VALUE}

A regional frequency curve is considered to be superior to an individual station frequency curve; however, an analysis must be made at each gaging station before a regional study can be started.

The flood history at a gaging station is a record of what has happened at that particular site during the specified period of observation which is relatively short, statistically speaking. Such a record is only a chance sample of the flood potential representing the overall flood-frequency relation and as such may be a poor example for predicting what will happen in the future, even at the same site.

\section{TYPES OF SERIES}

There are two methods in general use for studying the frequency of floods: an annual flood series and a partial-duration series.

An annual flood is defined as the greatest momentary peak discharge in a water year (October 1 to September 30). In the annual flood array, the recurrence interval is the

average interval in which a flood of a certain magnitude has occurred once as an annual maximum. An objection to the use of annual flood is that the second highest flood in a given high year may outrank many annual floods.

The partial-duration series is a list of all floods above a selected base. The base is generally selected as equal to the lowest annual flood so that at least one flood in each year is included. In the partial-duration series the recurrence interval is the average interval of time between floods of a given magnitude. An objection to the use of the partial-duration series is that the floods listed may not be fully independent events.

A definite relation exists between values in the two series as shown by Langbein (1949) and Chow (1950). The following table shows comparative values of recurrence intervals derived by the two methods:

Recurrence intervals in years

Annual flood series

$$
\begin{gathered}
1.16 \\
1.58 \\
2.00 \\
2.54 \\
2.52 \\
10.5 \\
20.5 \\
50.5 \\
100.5
\end{gathered}
$$

\section{Partial-duration series}

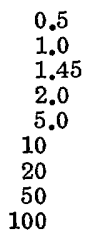


The annual flood series is used in this report. Where a frequency curve derived from the partial-duration series is desired, an annual-flood curve can be converted to the partial-duration series curve by the relation expressed in the preceding table.

\section{PLOTTING POSITION}

The analysis of flood data starts with a listing of all the annual peaks at a gaging station. These are ranked according to mag nitude starting with 1 as the highest. A time scale must be computed, to obtain a plotting position for the frequency scale. There are several methods, but the one used by the Sur vey and in this report is

$$
T=\frac{n+1}{m}
$$

where

$T$ is the recurrence interval in years,

$n$ is the number of years of record,

$m$ is the order of the mganitude of the flood, the highest being 1 .

In the study of historical floods, $n$ is the number of years in which it is known that the flood was of the order assigned.

Annual floods are plotted on a special form devised by Powell (1943) on which the dis charge is plotted on a linear scale as the ordinate and the recurrence interval on a scale graduated on the basis of the theory of extreme values as the abscissa.

\section{HISTORICAL DATA}

Historical floods can be used to extend the frequency curve of a station to cover a longer period. Historical data, however, are usually confined to stages or comparison of stages above a high base and it is important to define their order of magnitude with respect to a period of time. Historical information on small streams is more difficult to obtain than on larger streams because the duration of the flood is quite short and the number of people affected is very limited. Care must be exercised in assigning discharge values to historical stages because of possible channel changes.

Some information on historical floods was obtained, usually from local residents. Gen- erally it is confined to the maximum flood during the memory of one or possibly several individuals. Some of the stages noted are beyond the limits of the defined stagedischarge relation, and a discharge could not be estimated.

\section{FITTING FREQUENCY CURVES}

After the flood discharges for each station have been plotted against their computed recurrence intervals, a curve is drawn on the basis of the plotted points. The relatively short length of most streamflow records and the probable inaccuracies of small samplings do not warrant analytical curve fitting. There fore, a visual best fit smooth curve is used in this report to average the points. It is known that the maximum flood or floods of record may have a recurrence interval considerably greater than the period of record. Therefore, in drawing a best fit smoothfrequency curve, more weight is given to the lower floods than to the higher floods. Figure 3 shows a plot of the frequency of annual floods for Plum Creek near Smithfield, Nebr.

LIMITATIONS OF A SINGLE STATION ANALYSIS

Generally the 25-year or the 50-year flood is selected as the design flood. Table 1 shows that there are no gaging stations in Nebraska

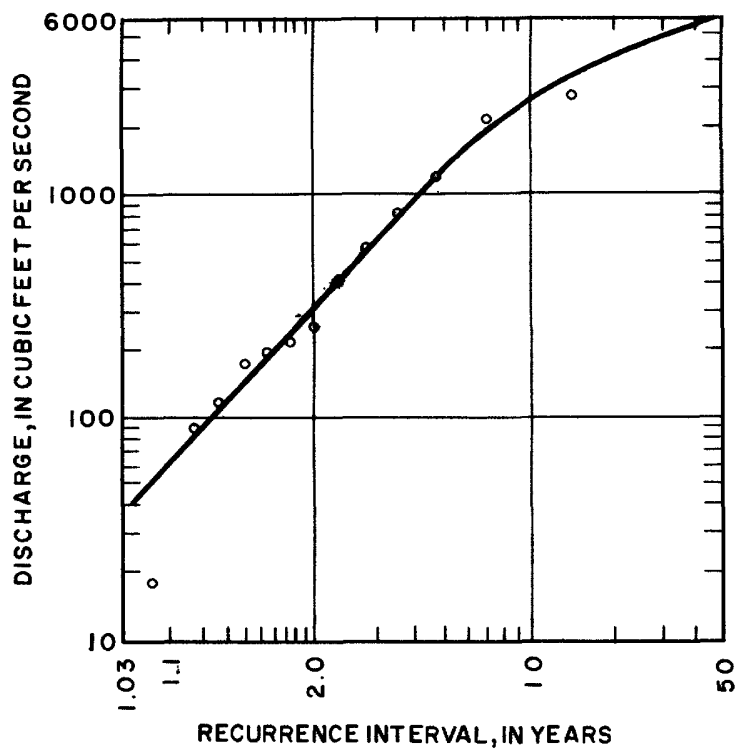

Figure 3. -Frequency of anmual floods, Plum Creek near Smithfield, Nebr. 
with less than a 300 square mile drainage area which have 50 years of record of annual peaks and that there are only 5 stations which have more than 25 years of record of annual peaks. Of the total 142 stations, 113 have only 10 years or less of record of annual peaks. To define a 25-year or 50-year flood would require extensive extrapolation from the trend of the plotting position of lesser floods. The error of the curve could be considerable at its outer extremity.

The random manner in which flood events are distributed with respect to time is another limitation to frequency graphs based on records at a single station.

The maximum departure to be expected between flood magnitudes or frequencies computed from relatively short records and their true (long-term) values increases with the magnitude of the flood and decreases with the length of record (Benson, 1960). The following table, based on Benson's study, shows the length of record required at a single site to define the frequency of floods of various magnitudes with 10 and 25 percent of the true value 19 out of 20 times.

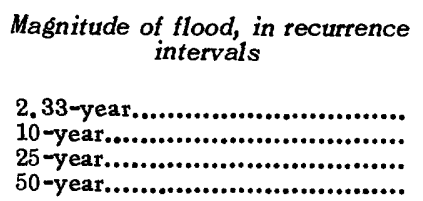

Length of record, in years 10 percent 25 percent

25 -year................................

50-year.

$\begin{array}{rl}40 & 12 \\ 90 & 18 \\ 105 & 31 \\ 110 & 39\end{array}$

Although the figures in the above table are based on a hypothetical study, they give an indication of the possible errors, from chance alone, in frequency graphs based on shortterm records for a single station. A comparison of the lengths of stream records available in Nebraska on drainage areas of 300 square miles and less (table 1) with those indicated by Benson (1960) suggests that very few records in the State are long enough to define reliably the mean annual flood, and the floods of infrequent occurrence are less accurately defined. Analysis on a regional basis is used as a solution to the floodfrequency definition.

\section{REGIONAL FLOOD-FREQUENCY ANALYSIS}

Aflood-frequency curve based on a number of stations has greater reliability than a curve from a single station. In order to com- bine the records for a number of stations, two requirements must be met. The first condition is that all the records must be reduced to a common time basis or base period, and the second is that the stations must have frequency graphs of the same general shape and slope, within limits of chance, so that they may be considered homogeneous.

\section{BASE PERIOD}

Table 1 shows graphically the length of usable records at the 142 gaging stations. Not all stations have records of the same length. If they are to be combined, records must be on the same time basis. The actual length of a short-period record of at least 5 years' duration can be extended by correlation with the long-term record of a nearby station. This correlation, however, is more sensitive for small streams than for larger streams and requires a long-term station in the immediate vicinity. Therefore, because there is such meager distribution of longterm stations within the State, the base period selected is 1947-59. Inasmuch as this base period is so short, it was also necessary to analyze records for 33 long-term stations having drainage areas greater than 300 square miles. This analysis was made for the period 1929-59 in order to establish the relation of the short base period to a 31 year period.

The actual record at each station either included or was extended to the 13-year base period, and for the 33 long-term stations mentioned above, to the 31 -year period by computing a discharge figure for each year of no record. These computed discharges, which are based on correlation with records for long-term stations, are used only to as sign the more nearly correct order numbers to annual peaks of record.

\section{DEFINITION OF MEAN ANNUAL FLOOD}

According to the theory of extreme values as applied to floods by Gumbel (1945), the arithmetic mean of the annual peak discharges in an infinitely long series is equal to the discharge corresponding to the 2.33year recurrence interval. This definition is generally accepted, and the 2.33-year flood determined graphically is used as the mean annual flood for this report. Annual-flood 
data for each of the individual gaging stations were adjusted to the 13-year base period (1947-59).

\section{HOMOGENEITY OF RECORDS}

The test for homogeneity of records involves determining whether differences in slopes of individual frequency curves are greater than might occur by chance in random sampling. This statistical test has a 95 -percent confidence level, that is, one station in 20 may plot outside the limits of the test graph. The slope of each individual station frequency curve is expressed by the ratio of the 10 -year flood to the mean annual flood. The average ratio derived from the group was multiplied by the mean annual flood for each individual station and the corresponding recurrence interval was determined from the station frequency graph. The recurrence interval thus obtained was then plotted against the effective length of record in years on the specially designed test graph. The effective length of record is the number of annual floods of record plus one-half the number of estimated annual floods used to complete the base period.

The test applied to the 142 gaging stations used in this report indicates two homogeneous flood regions in Nebraska which are designated as regions $A$ and $B$. The regional boundaries are shown in figure 4 . Region $B$ is the Sand Hills, and region A consists of the remaining part of the State. There are 132 stations in region $A$ and 10 stations in region $B$.

\section{GOMPOSITE FREQUENCY CURVES}

In order to compare flood records at dif ferent gaging stations and combine them to define composite flood relations, it is necessary to convert the floods to a dimensionless basis. This was done by computing the ratio of floods of selected recurrence intervals to the mean annual flood for each gaging station in a homogeneous region. The median ratio of each selected recurrence interval was then plotted against the corresponding recurrence interval to give the composite frequency curve for each homogeneous region (fig. 5).

\section{RELATIONS OF MEAN ANNUAL FLOOD}

The composite frequency curves as derived in the preceding section define dimensionless ratios of the mean annual flood to floods of other recurrence intervals. In or der to define the flood-frequency curve in terms of discharge for a specific site, the magnitude of the mean annual flood is required. The magnitude of the mean annual flood is obtained by relating it to measurable characteristics of the drainage basin.

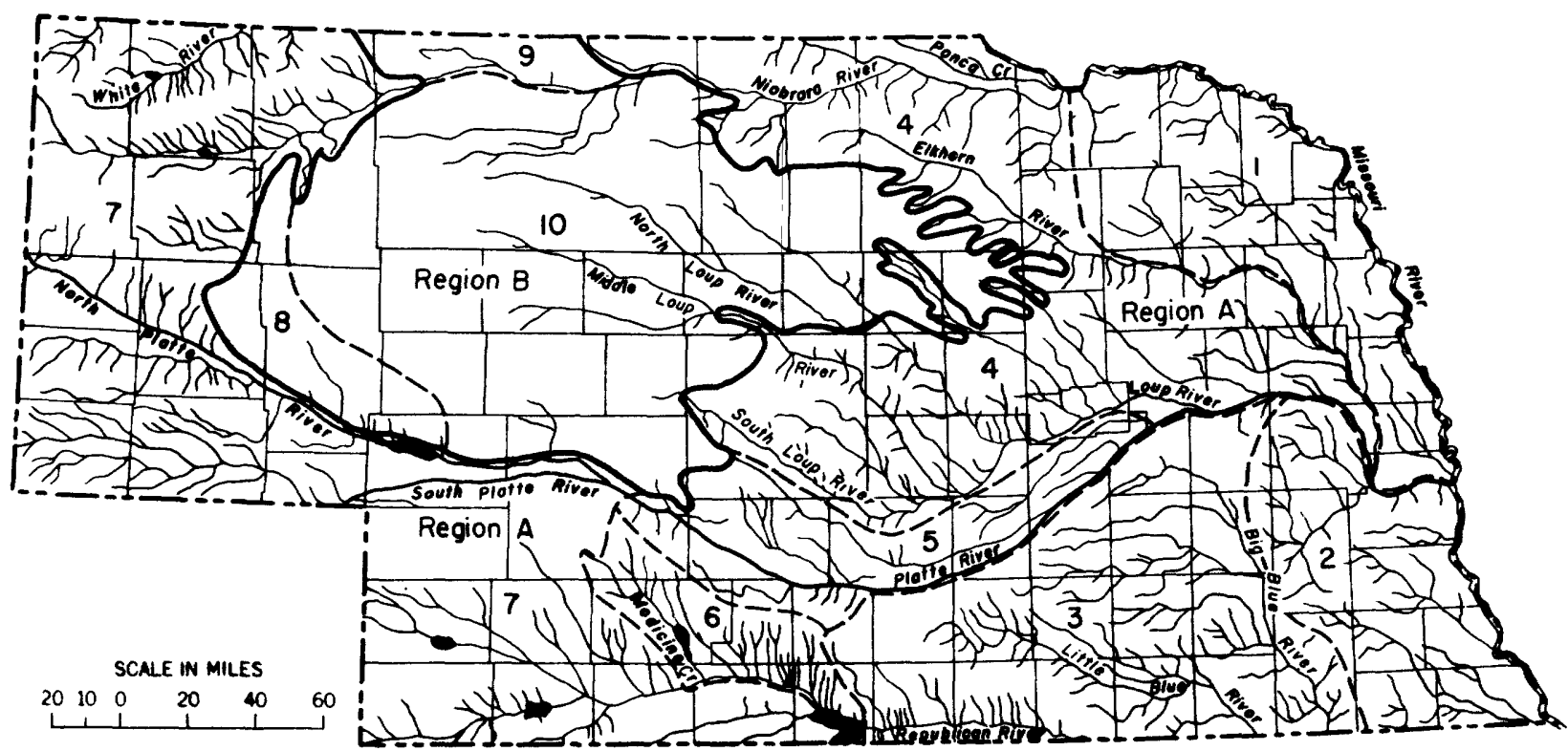

Figure 4. -Map of Nebraska showing flood-frequency regions and hydrologic areas. 


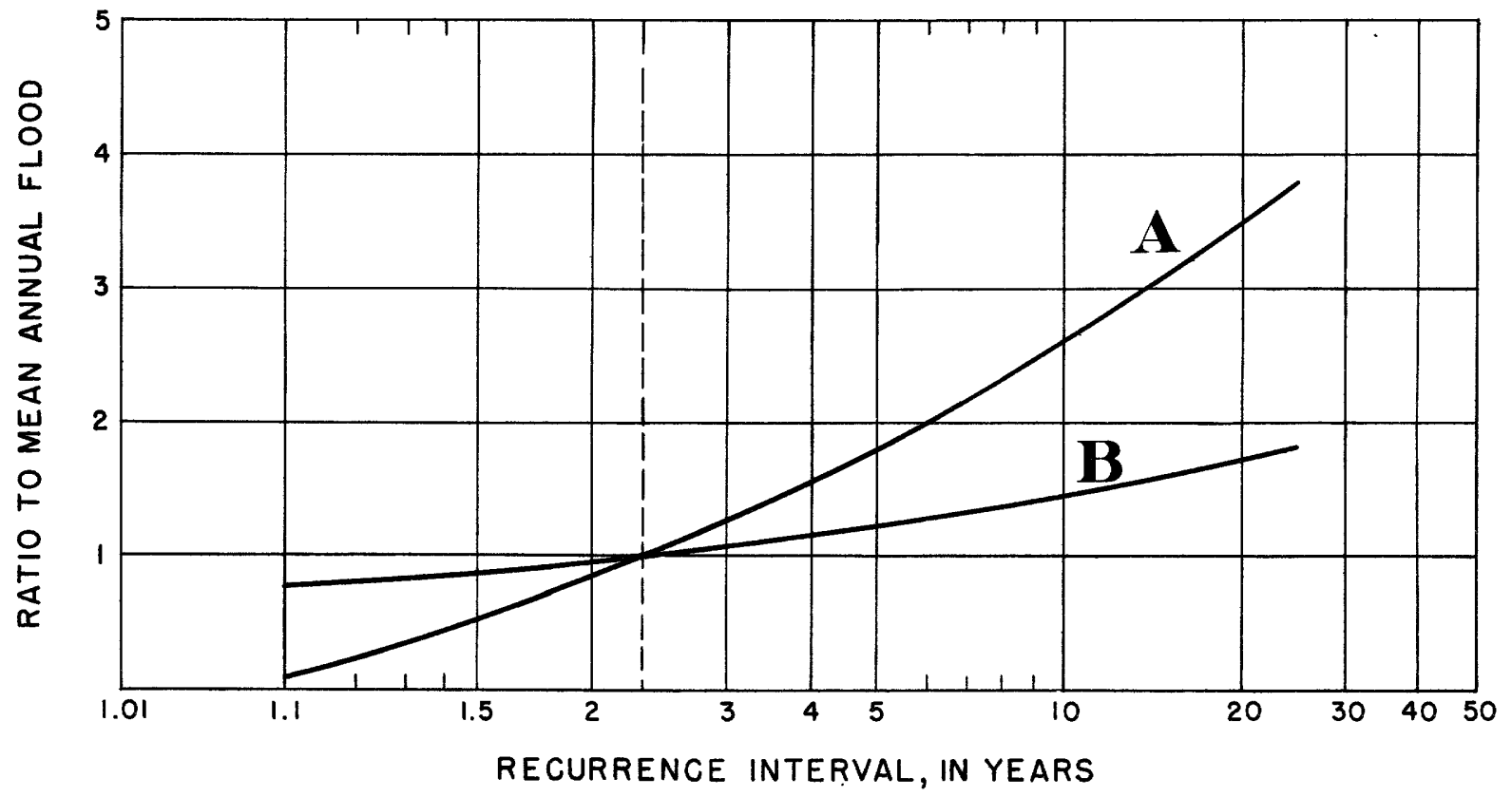

Figure 5. - Composite frequency curves of annual floods, regions A and B, period 1947-59.

The physiographic factors which may influence the mean annual flood at a given point are size of the drainage basin, shape of the basin, alinement of the basin with the prevailing direction of storm travel, channel storage, artificial or natural storage in lakes or ponds, slope of stream, land slope, stream density, stream pattern, altitude, depth and porosity of soil mantle, vegetal cover and land use. Some of these factors are difficult to evaluate and therefore cannot be used in a correlation.

The mean flow of a stream is a hydrologic measure that integrates all factors of runoff and thus includes an indication of flood potential. Because the majority of the station records used in this report are from crest stage gages at which total runoff is not meas ured, the mean flow had to be determined from streams which have larger drainage areas and which are not always strategically located.

The mean annual flood was correlated graphically with contributing drainage area, mean flow, stream slope, and shape of basin factor. The drainage area size, the mean flow, and stream slope are all significant factors, drainage area and mean flow being the most significant. The correlations, how ever, do not give consistent results and inas much as mean flow was inadequately defined, the contributing drainage area alone was

used to define a relation with the mean annual flood. Along with variations in mean flow, other factors or combination of factors that influence floods are not reflected in the size of the basin, but their effect is related in areas having somewhat similar physical features. Accordingly, the State was subdivided into 10 hydrologic areas shown in figure 4. Except for the boundaries of the regions $A$ and $B$ which are also boundaries of hydrologic areas, the boundaries of the hydrologic areas follow the drainage divides or major streams.

Records for the 33 long-term stations mentioned under "Base Period" above were used in order to define mean annual flood relations with respect to time. The graphical definition of the mean annual flood for the 31-year (192959) base period was compared to the mean annual flood defined by the 13-year (1947-59) base period at each of the 33 individual sta tions which are distributed around and within the State. This study revealed that the aver age correction factor required to adjust the mean annual flood from the 13-year period to the 31 -year period in the 10 hydrologic areas is as follows:

Area

1 and 2.

3 and $4 . \ldots \ldots \ldots \ldots \ldots \ldots \ldots \ldots \ldots \ldots \ldots \ldots \ldots \ldots$

$5,8,9$, and $10 \ldots \ldots \ldots \ldots \ldots \ldots$

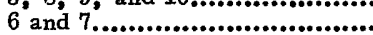

Correction factor

$$
\begin{aligned}
& 0.816 \\
& .925 \\
& 1.00 \\
& 1.08
\end{aligned}
$$


The above adjustments are reasonably well established in all areas except in area 7 where there is considerable spread in results for individual stations used to define the average correction.

The mean annual flood for each station determined from the 13-year period was corrected by the average correction factor for the hydrologic area in which the station was located. For each of the 10 hydrologic areas, the corrected mean annual flood for each station in that area was plotted against the contributing drainage area for the station. Curves were drawn to average all the data in each area. The variation of mean annual flood with contributing drainage area for each of the 10 hydrologic areas is shown in figure 6.

\section{HYDROLOGIC AREAS}

Area 1 , as shown in figure 4 , is the northeast corner of the State. It includes all the smaller streams downstream from the Niobrara River and upstream from the Platte River which are direct tributaries of the Missouri River. It also includes the left bank tributaries of the Elkhorn River which are downstream from the Sand Hill area. The area is generally quite hilly. The variation of the mean annual flood with drainage area is defined by 15 stations.

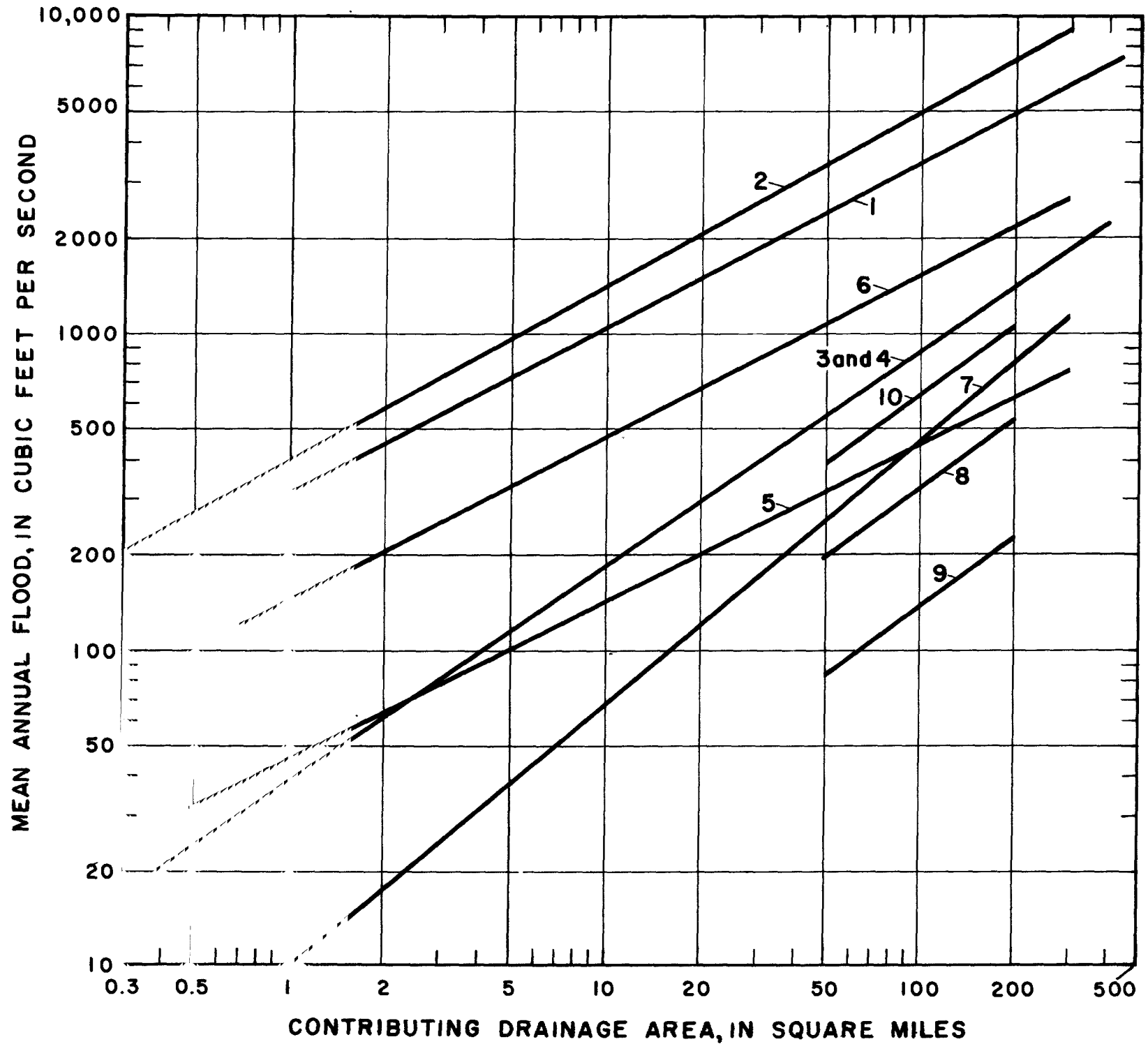

Figure 6. -Variation of mean annual flood with contributing drainage area in hydrologic areas 1-10. 
Area 2 is the southeast corner of the State. It includes Salt Creek, a tributary of the Platte River, and all direct tributaries of the Missouri River in the State downstream from the Platte River. This area is also quite hilly except for a flat area in Saunders County which probably is the remains of an old Platte River channel. The five Silver Creek stations included in this report are in this flat area and their drainage areas include many depressions which trap water and prevent it from reaching the stream. Available topographic maps for this flat area do not distinguish between the contributing and the noncontributing area. Twenty-five stations are in area 2 , but because the contributing drainage of the five Silver Creek stations is not defined, the curve of variation of mean annual flood with drainage area is drawn on the basis of the data from the 20 remaining stations. The mean annual floods are higher than those in area 1 because of the greater mean annual rainfall and resulting greater mean flow.

Area 3 (fig. 4) consists of the south-central plains of the State. It contains the Big Blue River, the Little Blue River, and the tributaries of the Republican River downstream from Harlan County Dam. The headwaters of these streams drain gentle sloping land, and there are some depressions which trap runoff and prevent it from reaching the streams. Seventeen stations are used to define the variation of the mean annual flood with drainage area.

Area 4 (fig. 4) includes Ponca Creek, the tributaries of the lower part of the Niobrara River, the upper part of the Elkhorn River and all its right-bank tributaries, the Loup River basin downstream from the Sand Hills, and the left-bank tributaries of the Platte River between the Loup River and the Elkhorn River. This area has a wide variety of topography and soils. Flood flow at some of the stations is materially affected by the proximity of the porous Sand Hills. Generally, it is possible to determine the contributing drainage area if good topographic maps are available. Good topographic maps have not been made for this area; therefore, some of the drainage areas are listed as approximate. Twenty-eight stations are used to define the variation of the mean annual flood with the contributing drainage area. The resulting curve is so similar to that for area 3 that one curve is shown on figure 6 as representative of both hydrologic areas.
Area 5 (fig. 4) includes the small tributaries of the Platte River in the central part of the State. The area contains some low rolling hills at the headwaters of the streams and at the perimeter of the area but toward the interior the land and stream slopes become less. As the drainage area increases, channel storage becomes a factor in reduction of the mean annual flood. Twenty-one stations are used to define the variation of the mean annual flood with drainage area.

Area 6 (fig. 4) includes the Medicine Creek basin and all left-bank tributaries of the Republican River between Medicine Creek and Harlan County Dam. This area is very hilly and contributes to surface runoff, except for the upper reaches of the Medicine Creek basin where part of the Sand Hills is located. Thirteen stations are used for defining the variation of the mean annual flood with the drainage area.

Area 7 (fig. 4) is the western part of the State that includes drainage basins of the Republican, South Platte, North Platte, Niobrara, and White Rivers. This area has a wide variety of topography and soils. Some parts of the Republican River basin have depressions and sandy areas which do not contribute to surface runoff. Thirteen stations are used to define the relation of the mean annual flood to the contributing drainage area. The definition in area 7 is considered to be the poorest in the State.

Area 8 is the southwestern part of the Sand Hills as shown in figure 4 ; it is defined on the basis of only one station record. The station frequency curve indicates that mean annual floods are considerably lower than those defined in area 10 . The relation of the mean annual flood to contributing drainage area is defined by the one station and the slope of the relationship curve defined in area 10.

Area 9 (fig. 4) is the part of the Sand Hills north of the Niobrara River. As in area 8 , only one station record is available. The station frequency curve indicates that mean annual floods are considerably lower than those in area 10. The relationship curve, as shown in figure 6 , is based on the one station record and the slope of the relationship curve defined for area 10.

Area 10 (fig. 4) contains the greater part of the Sand Hills which generally drain to the 
south and east. Only the area immediately adjacent to the streams contributes to surface runoff; the high base flow comes from ground water. The contributing drainage areas of the eight stations in this area are not very well defined and are listed as approximate. The range in size of the contributing drainage area is from 50 to 140 square miles.

The definition of the mean annual flood with respect to contributing drainage area covers the range of drainage area from 1 to 300 square miles in hydrologic areas $1-7$. The range of drainage area defined in areas 8-10 is from 50 to 200 square miles.

\section{APPLICATION OF REGIONAL FLOOD.FREQUENCY DATA}

\section{TRIBUTARY AREAS OF NATURAL RUNOFF}

This section gives step-by-step procedures for determining the magnitudes of floods in Nebraska having any recurrence interval up to 25 years at any site not subject to manmade regulation or control that has a contributing drainage area between 1 and 300 square miles in region $A$ and between 50 and 200 square miles in region $B$ (fig. 4 ).

1. Determine the total and contributing drainage areas at the site. The contributing drainage area is that part of the total basin area that contributes directly to surface runoff.

2. From figure 4, obtain the number of the hydrologic area and the flood region in which the site is located.

3. With the contributing drainage area (step 1) and the number of the hydrologic area (step 2), determine the mean annual flood for the site from figure 6 .

4. With the flood region (step 3) determine the ratio to the mean annual flood for the flood of the selected frequency of recurrence from figure 5 .

5. Multiply the ratio of the selected flood to the mean annual flood (step 4) by the mean annual flood determined in step 3 to obtain the flood magnitude at the site. If a complete frequency graph is desired, repeat steps 4 and 5 for a number of recurrence intervals.
It must be emphasized that the curves cannot be extrapolated with confidence beyond the limits of the base data from which the curves were derived.

\section{STAGE OF FLOOD DISCHARGE}

This report deals specifically with the frequency of flood discharges. Flood stage corresponding to these discharges may also be of primary concern in the design of certain structures and in other related studies. For rock-lined or firm-bedded streams at sites not subject to variable backwater from downstream inflow or structures, a stage-discharge relation provides a ready solution to the problem. For shifting-channel streams of Nebras $\mathrm{ka}$ and where variable backwàter may exist, the stage corresponding to the selected discharge may be approximated only after extensive research. If the stage is to be investigated, the engineer will find the site in question to be in one of two categories:

1. Site at or near an established gaging station. Gaging stations have been maintained at several hundred sites in Nebraska. Locations of those established prior to September 30,1950 , are described in reports of the Geological Survey (Water -Supply Papers 1309 and 1310). Stations established since 1950 are described in the annual series of watersupply papers entitled "Surface Water Supply of the United States." A reasonable stagedischarge relation has been established at each of the small-area stations used for this report, and may be examined in the Lincoln office of the Geological Survey. For sites at or near gaging stations, it is usually possible to obtain stage data that are adequate for most purposes.

2. Site not near an established gaging station. The stage corresponding to a discharge of selected recurrence interval must generally be obtained through the medium of a stage-discharge relation. The extent of the investigation required to establish such a relation will depend upon the accuracy requirements. The following methods of deriving a stage-discharge relation are noted in decreasing order of reliability. (a) If the need for data can be anticipated far enough in advance, discharge measurements may be obtained to define the relation up to the maximum discharge observed in the period. The 
relation may be extended by the application of measured channel characteristics to appropriate hydraulic formulas. Shifting -channel characteristics may be investigated by studies of bed material and some long-term changes may be obtained from local residents. (b) If the need for data is immediate, the dis charge for a past flood may be computed by hydraulic formulas if adequate floodmarks can be recovered and one point on the stage discharge relation curve thereby established. A direct measurement of discharge at the time of the visit will provide one other point. (c) A method has been used to develop ratings for stable channels from the product of the stream slope at zero flow or low flow and characteristics of conveyance at a typical cross section. This method is unsuited to streams with unstable channel beds.

\section{MAXIMUM KNOWN FLOODS}

The design of major hydraulic structures whose failure may cause loss of life should consider the maximum probable flood rather than one that may be expected to occur in a defined period of years. A prerequisite to such an analysis is the record of maximum known floods.

Maximum known stages and discharges at the 142 gaging stations used in the floodfrequency analyses are shown in table 2. The stations are listed in downstream order and the number preceding the station name corresponds with the numbers shown in table 1 and figure 2. The flood region and hydrologic area in which the station is located is shown as well as the total and contributing drainage area. The contributing drainage area is used to compute the peak discharge in cubic feet per second per square mile. The period of known floods is that for which the stage or discharge is known to be the greatest. The stage is given for each maximum discharge except for stations 7730 and 7829. The dis charge at these two stations had been determined from an indirect measurement prior to the establishment of the gage and there is no datum tie between the survey and the gage. Where the maximum stage and the maximum discharge are not concurrent, a change in the stage-discharge relation is indicated, and no discharge figure is shown for the maximum stage. Some periods of known floods for the maximum stage are extended on the basis of recovered floodmarks beyond the period of known floods for the maximum defined discharge. For such periods, a leader line has been placed in the discharge column to indicate that the discharge for this known stage could not be defined within allowable limits of accuracy. A leader line in other columns is also used to indicate that the information could not be determined.

Twenty-five unusual peak discharges have been collected at miscellaneous sites or at short-term gaging stations which have 300 square miles or less contributing drainage area. These data are shown in table 3. The sites are listed in downstream order. Gaging stations having records of insufficient length to be included in the flood-frequency analysis have been operated or are being operated at numbered sites. Unnumbered sites are miscellaneous sites where only one observation has been made.

As shown in figure 5 , there is a great difference in the composite frequency curve for region $A$ and for region $B$, and the curves of figure 6 show that the mean annual flood for a given drainage area can vary considerably between hydrologic areas. A separate illus tration was developed, therefore, for each of the 10 hydrologic areas on which the 10 - and 25-year recurrence interval floods are shown as a curve to compare with the maximum discharge at the stations and miscellaneous sites in that hydrologic area. The maximum discharge at the 142 stations used in this frequency analysis are shown as open circles, and the maximum discharge at the miscellaneous sites and short-term gaging stations which are listed in table 3 are shown as closed circles. The gaging stations are identified by the last four or five digits of the index number, in order to correspond with those shown in tables 2 and 3.

The relation of the maximum discharge to the 10-and 25-year floods in the 10 hydrologic regions are shown in figures $7-11$. 


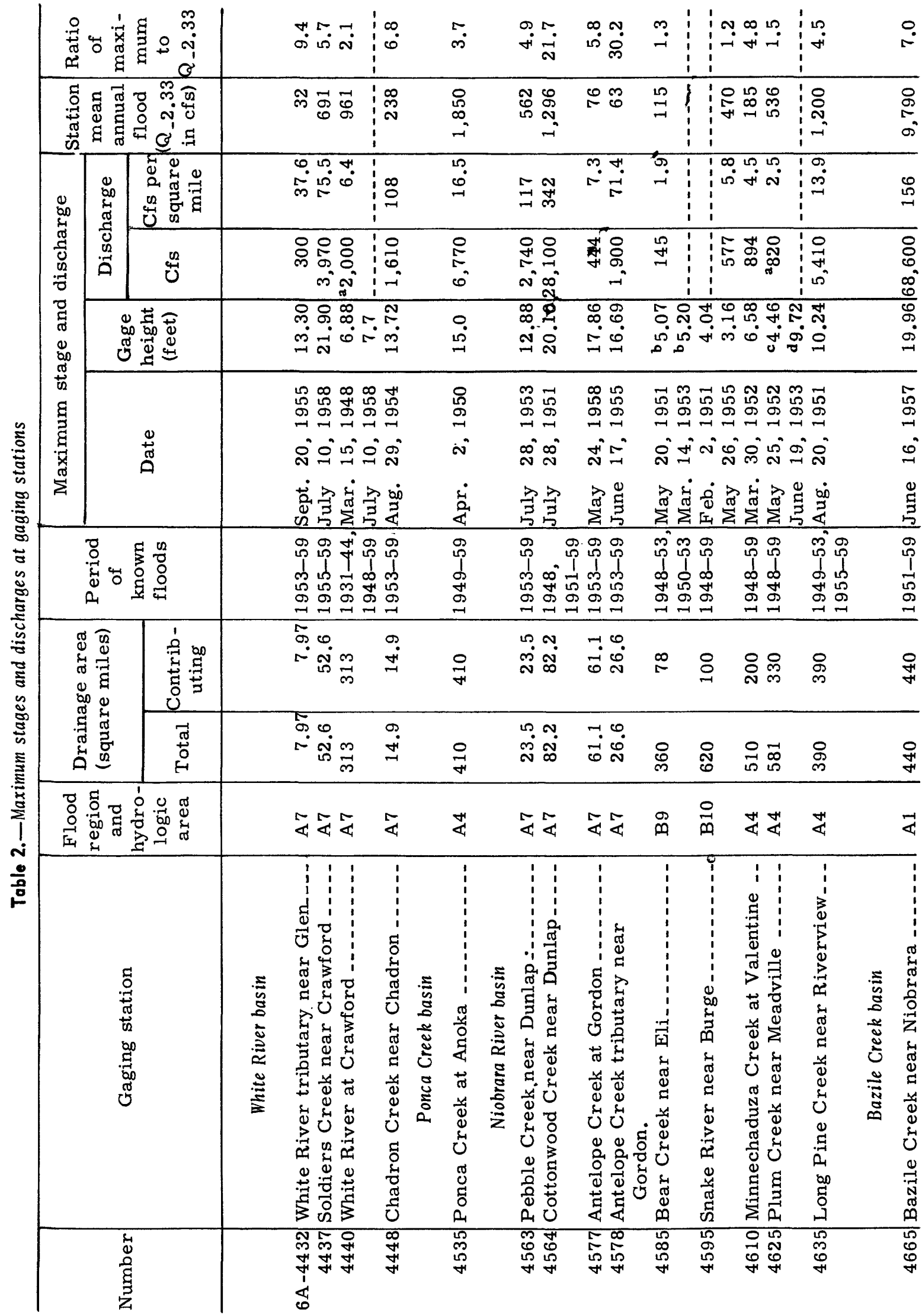




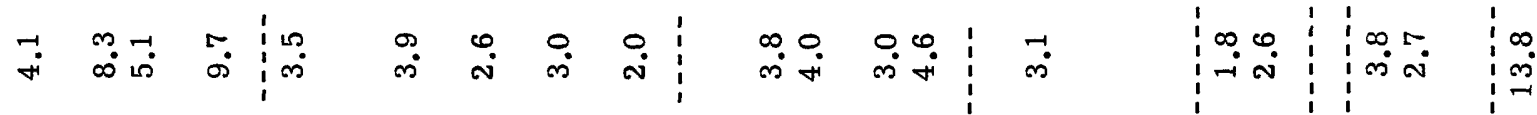

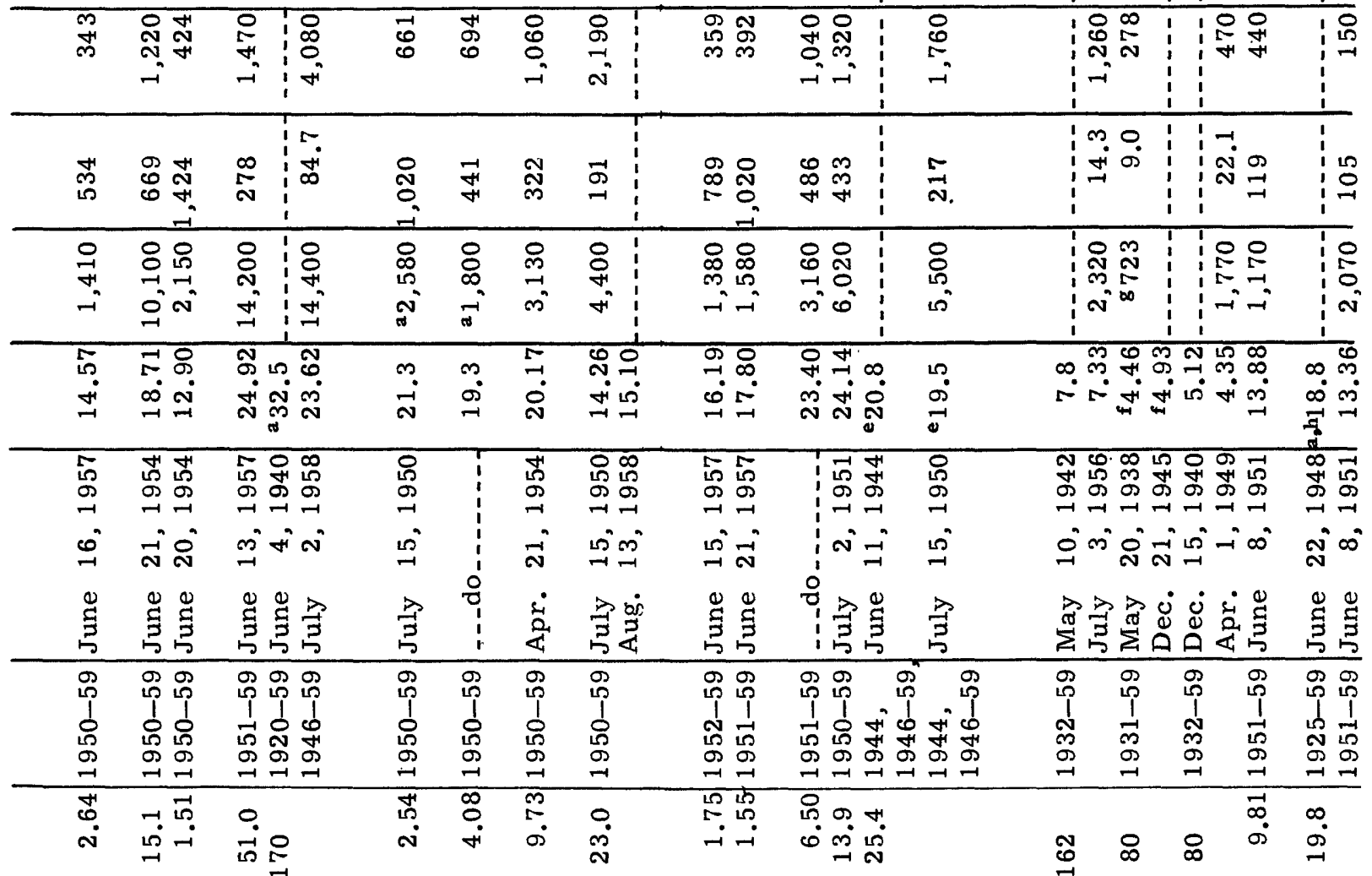

\begin{tabular}{|c|c|c|c|c|c|c|c|c|c|c|c|c|c|}
\hline $\begin{array}{l}\vec{J} \\
\text { i. }\end{array}$ & $\overrightarrow{\vec{n}}$ & $\stackrel{0}{\text { in }}$ & $\begin{array}{l}\text { 岁 } \\
\text { ง. }\end{array}$ & $\begin{array}{l}\infty \\
\circ \\
\circ\end{array}$ & $\stackrel{m}{\tilde{D}}$ & $\begin{array}{l}0 \\
\text { N }\end{array}$ & 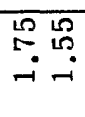 & 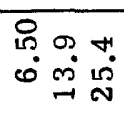 & ֻే & $\stackrel{\leftarrow}{0}$ & $\stackrel{\infty}{\mathscr{N}}$ & $\begin{array}{l}\vec{\infty} \\
\dot{\infty}\end{array}$ & $\stackrel{\infty}{\circ}$ \\
\hline
\end{tabular}

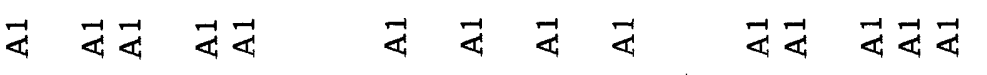

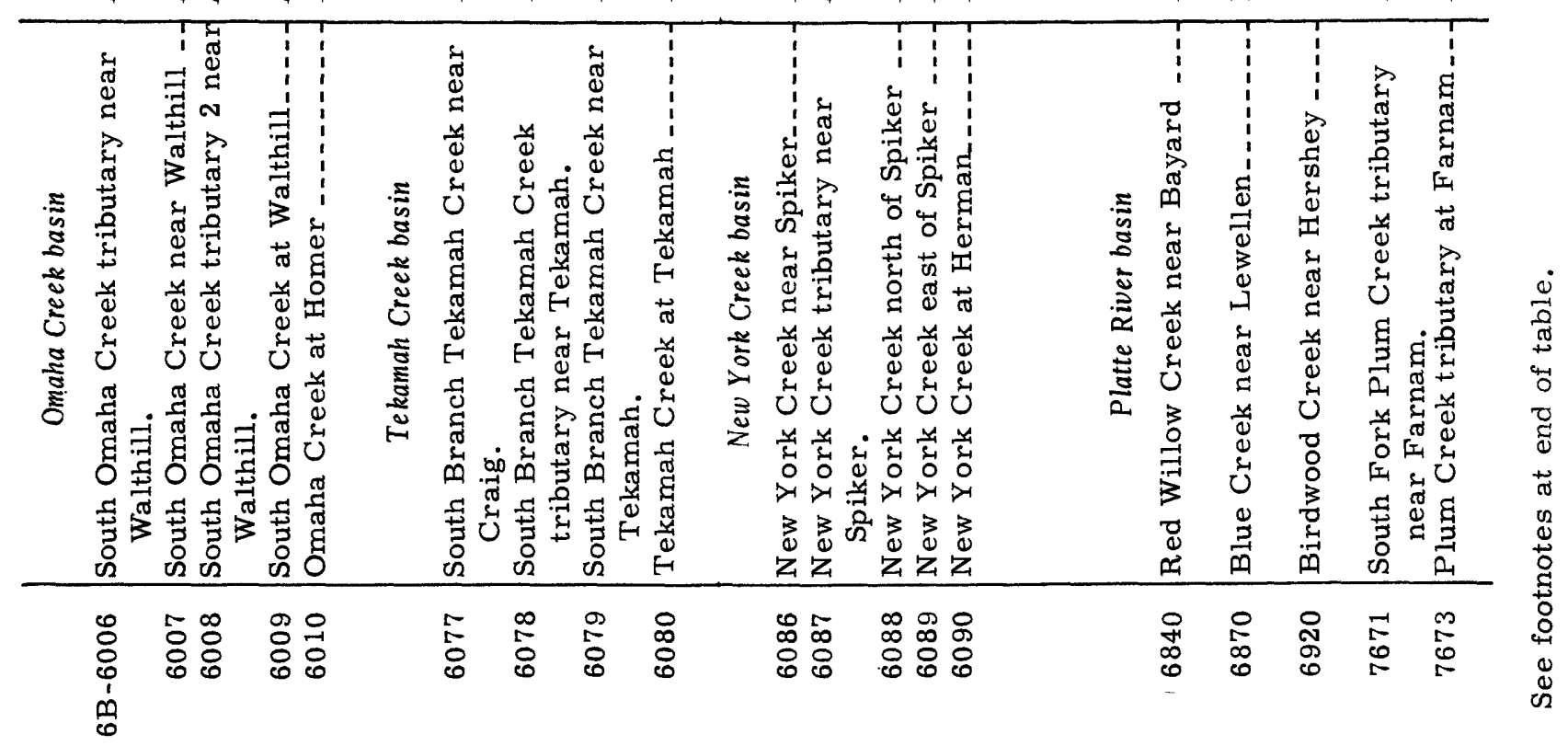




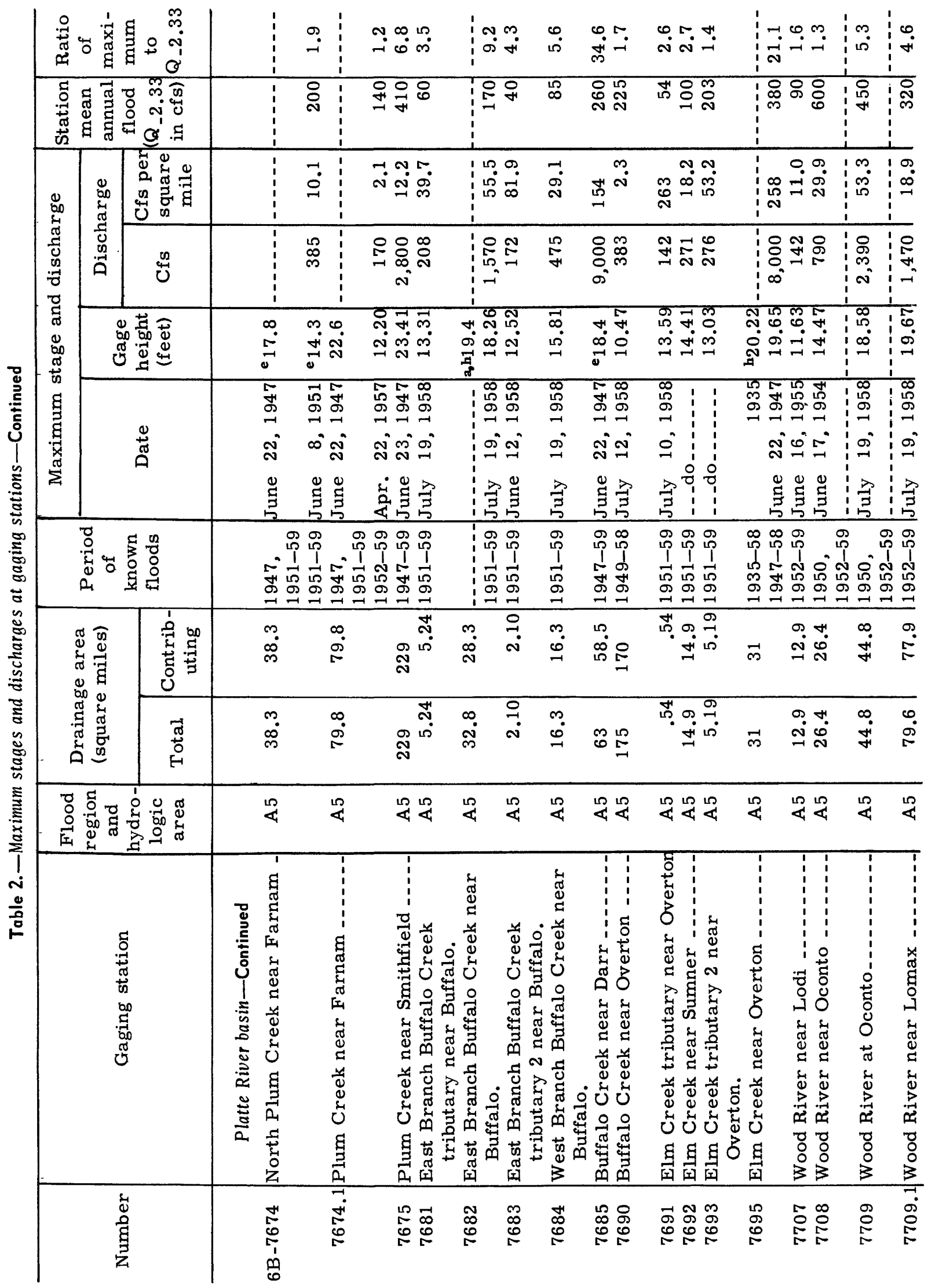




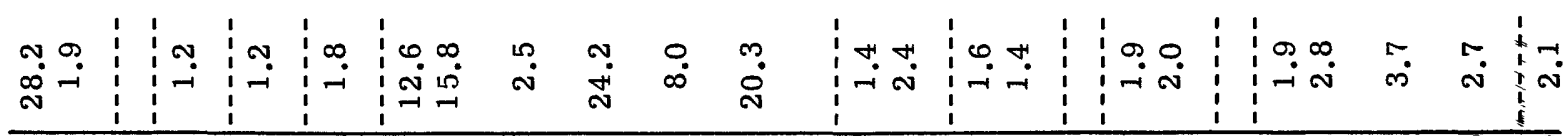
秀员

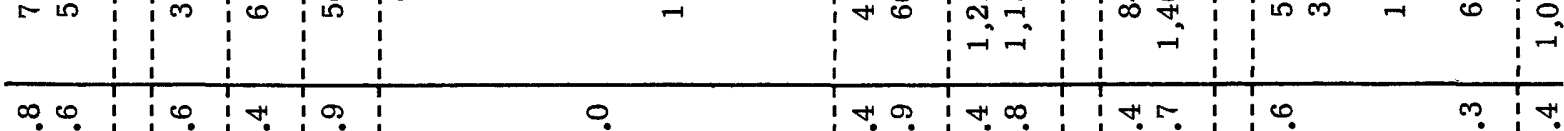

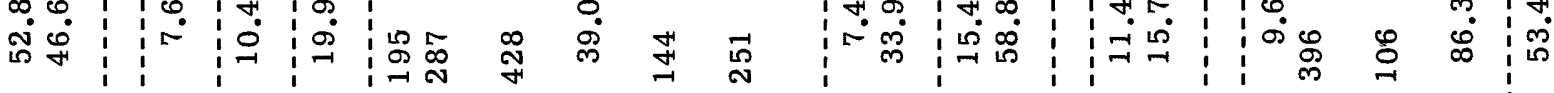

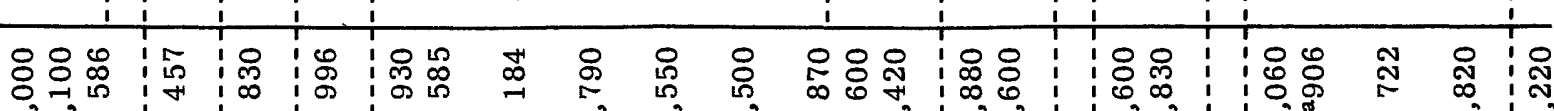

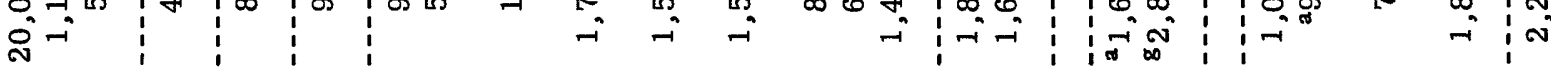

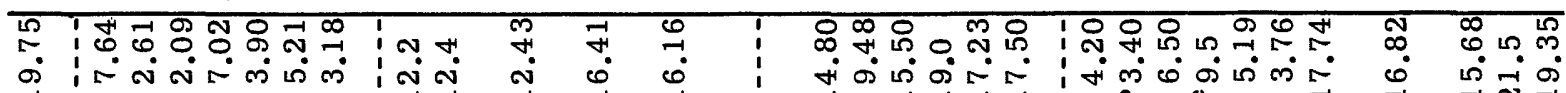

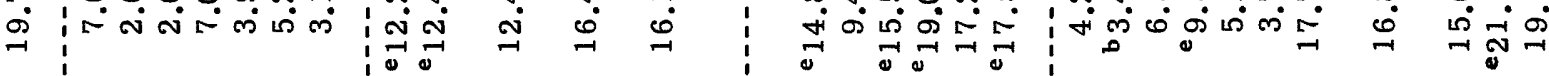

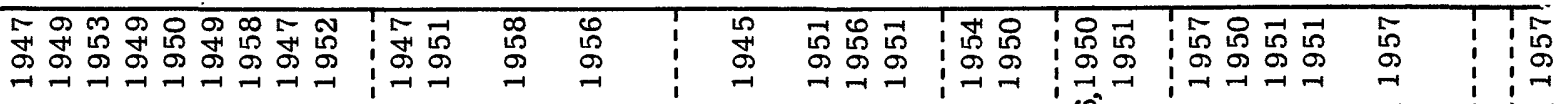
สิ

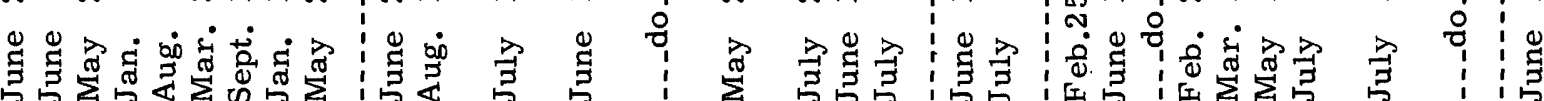
దำ l.

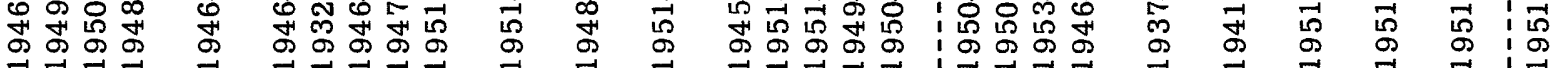

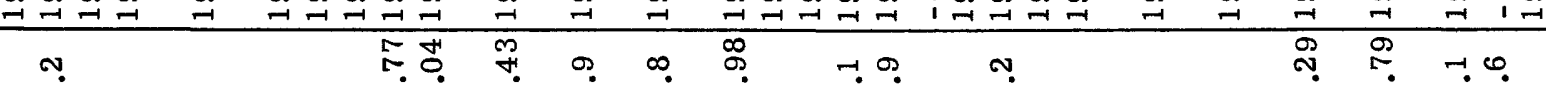

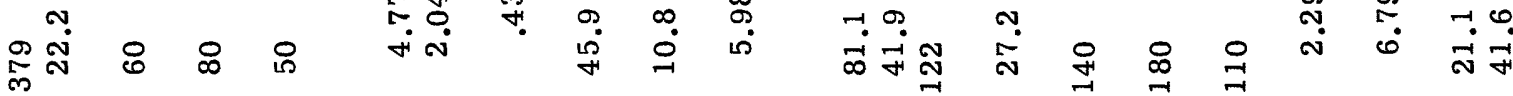

\begin{tabular}{|c|c|c|c|c|c|c|c|c|c|c|c|c|c|c|c|c|}
\hline ฉ & $\begin{array}{l}\text { O } \\
\text { - } \\
-1\end{array}$ & $\begin{array}{l}8 \\
0 \\
-1\end{array}$ & 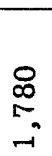 & 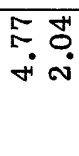 & m & 욤 & "م. & \begin{tabular}{l}
$\infty$ \\
\multirow{0}{\infty}{} \\
in
\end{tabular} & 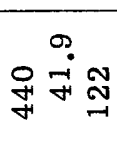 & ָั & $\begin{array}{l}8 \\
\infty \\
\infty \\
-1\end{array}$ & $\begin{array}{l}0 \\
\stackrel{1}{N} \\
\text { N }\end{array}$ & $\begin{array}{l}8 \\
\bigotimes \\
\text { N. } \\
-1\end{array}$ & & \% & $\begin{array}{l}\because 0 \\
\vec{N}\end{array}$ \\
\hline$\stackrel{10}{<}$ & $\begin{array}{l}\text { 음 } \\
\text { m }\end{array}$ & $\begin{array}{l}\text { O } \\
\vec{M}\end{array}$ & $\begin{array}{l}\text { O } \\
1\end{array}$ & $\underset{4}{*}$ & $\stackrel{Z}{Z}$ & $\mathbb{Z}_{4}^{+}$ & $\stackrel{+}{4}$ & $\stackrel{\nabla}{Z}$ & 出出芯 & $\sharp$ & $\begin{array}{l}0 \\
0 \\
0\end{array}$ & $\frac{0}{10}$ & 응 & $\stackrel{+}{4}$ & 荌 & \\
\hline
\end{tabular}

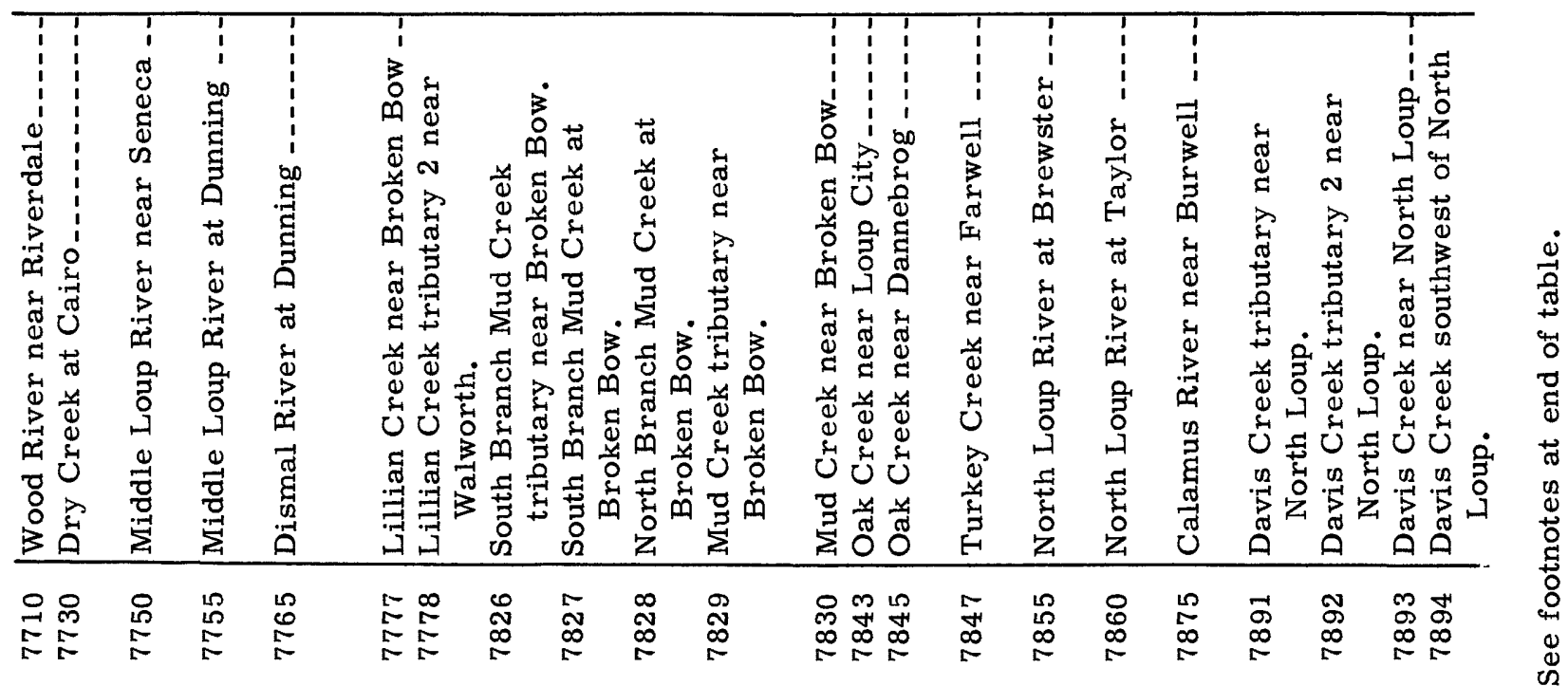




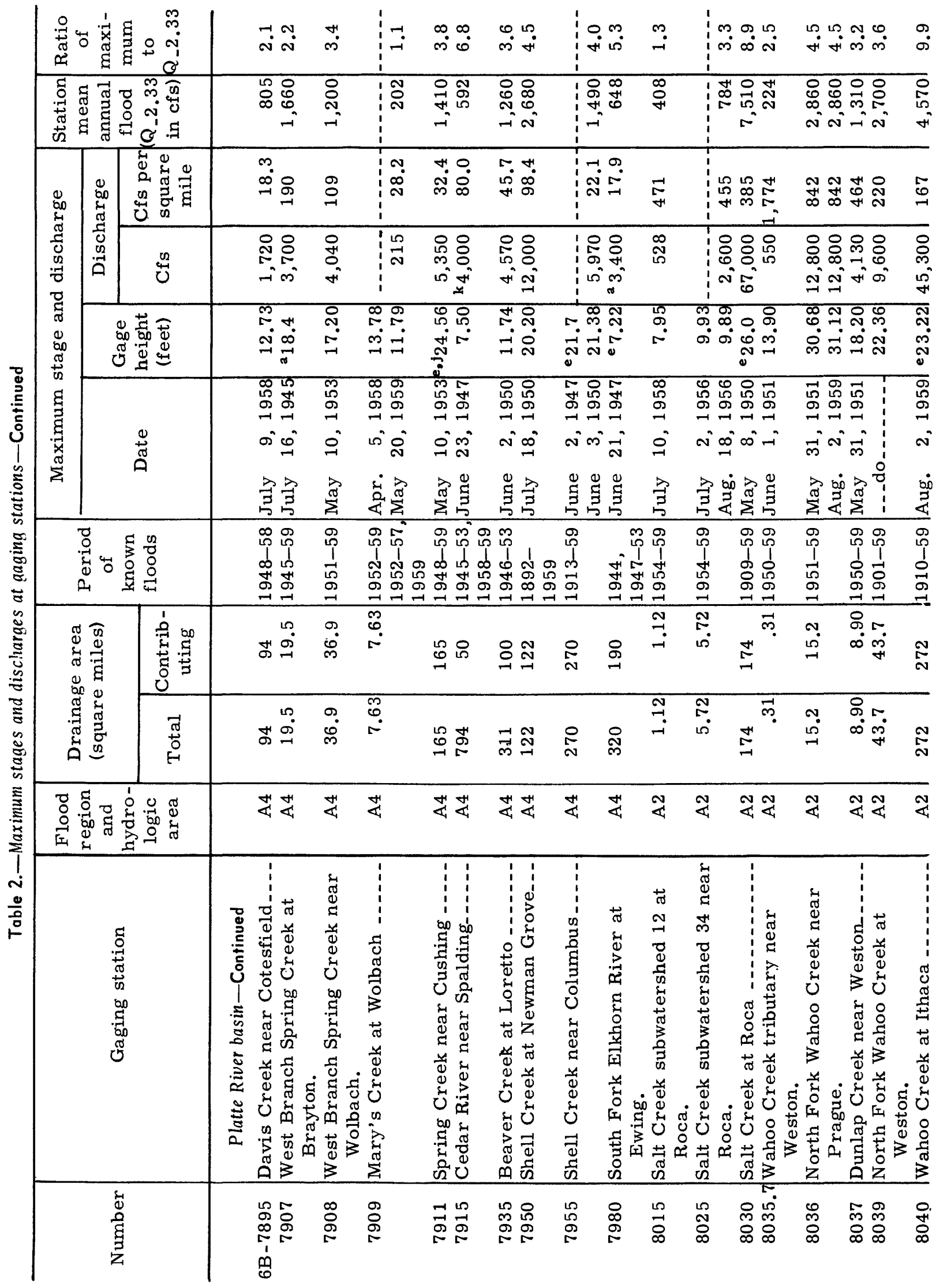


ஸ்

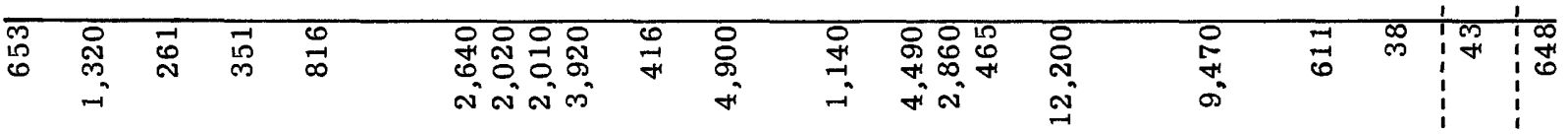

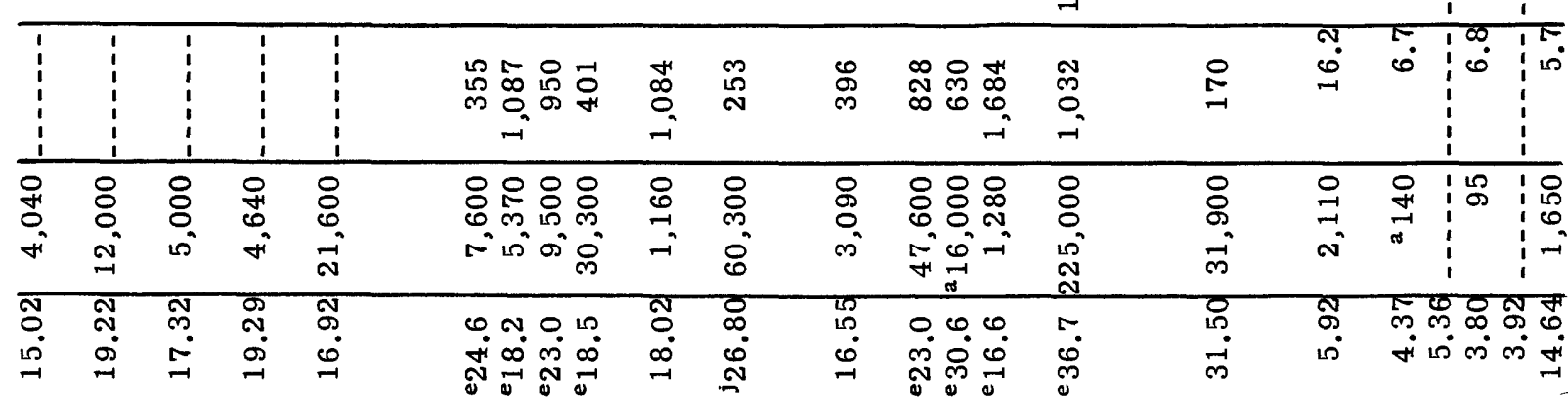

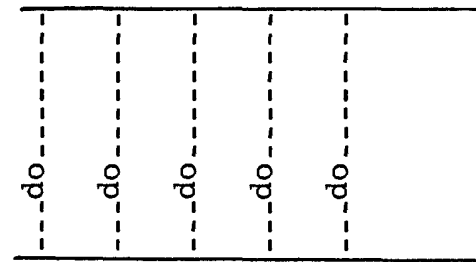

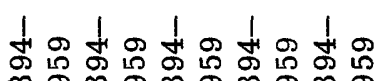

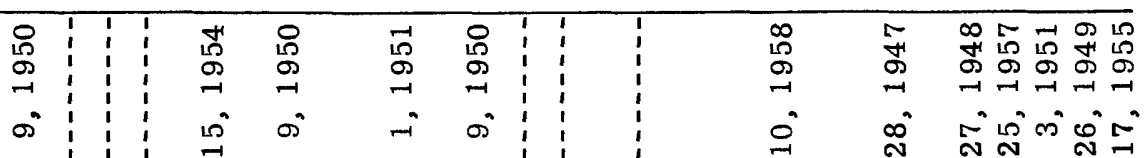

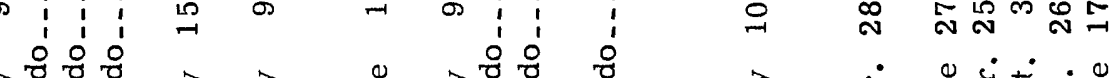

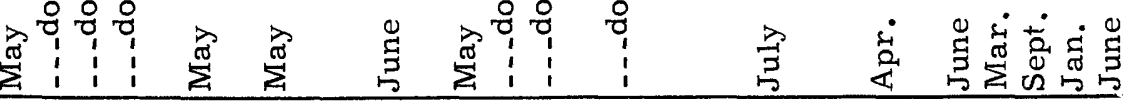

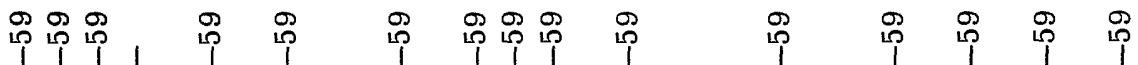
$\infty \infty_{\infty} \infty \infty \infty$

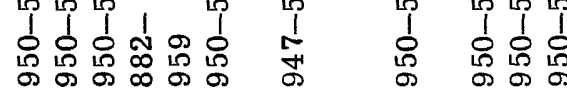

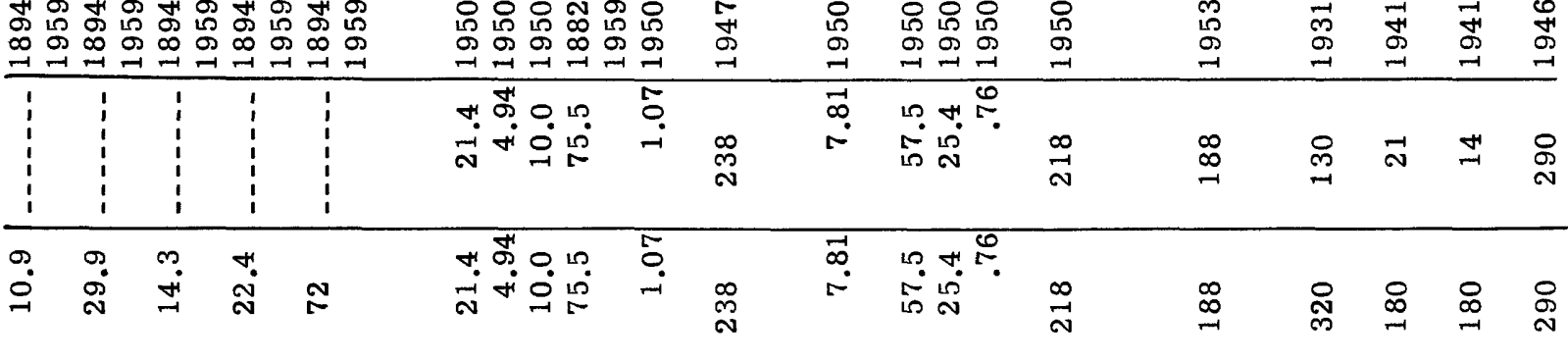

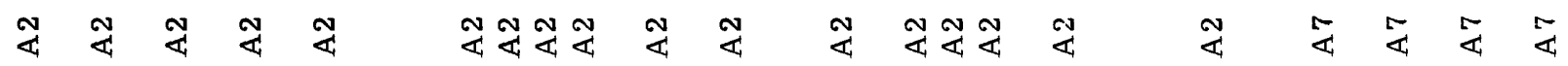

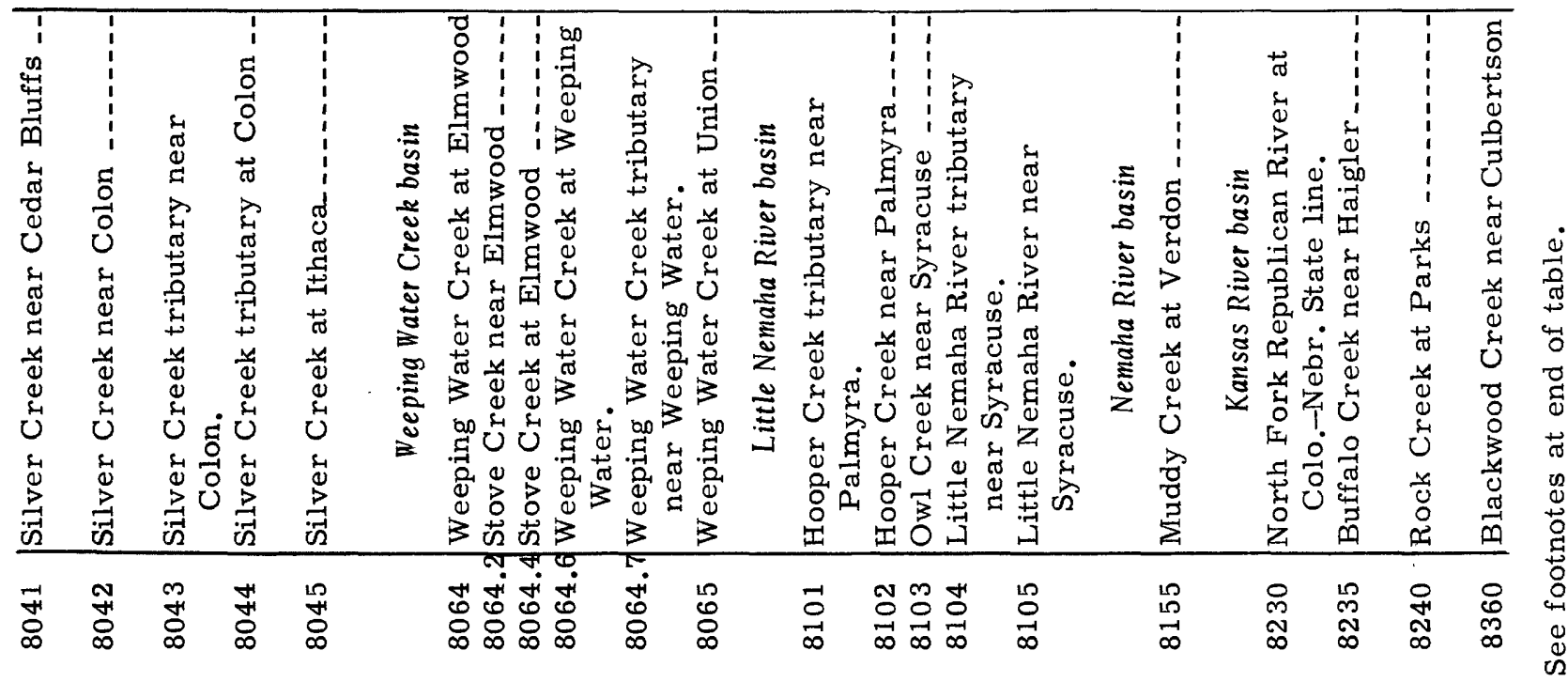




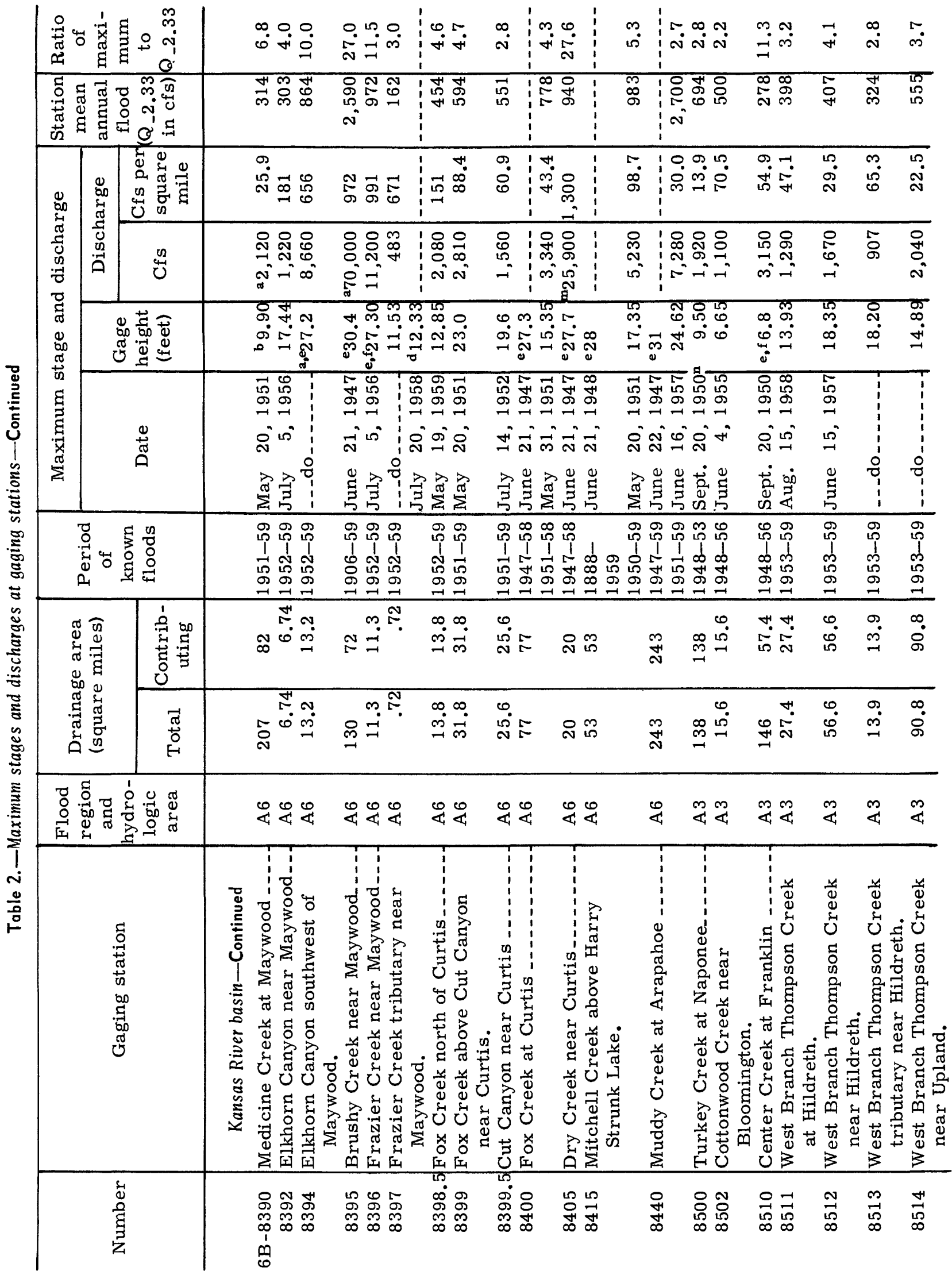




\begin{tabular}{|c|c|c|c|c|}
\hline ம் & $\stackrel{\sim}{\sim} \underset{\sim}{*}$ & サ̆ & \& & $\begin{array}{l}\infty \\
0 \\
\infty\end{array}$ \\
\hline 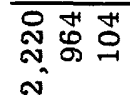 & $\begin{array}{l}\text { OM } \\
\text { \& }\end{array}$ & $\begin{array}{ll}\infty & 10 \\
\infty & \infty \\
\infty & \infty \\
\infty & -1\end{array}$ & స్. & i⿱ 口) \\
\hline
\end{tabular}

ก.

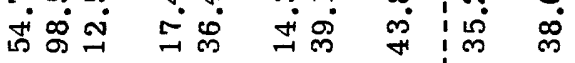

\begin{tabular}{|c|c|c|c|c|c|}
\hline 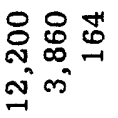 & $\stackrel{8}{\circ} \frac{0}{15}$ & 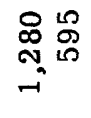 & $\underset{\infty}{\stackrel{8}{+}}$ & & 亲 \\
\hline
\end{tabular}

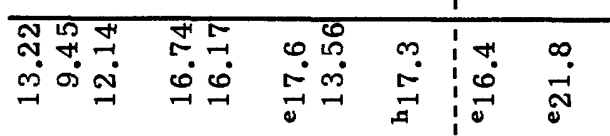

\begin{tabular}{|c|c|c|c|c|c|}
\hline 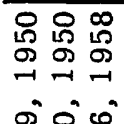 & $\begin{array}{l}\infty \\
\stackrel{\circ}{\circ} \\
\stackrel{-1}{-1}\end{array}$ & 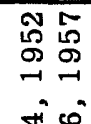 & 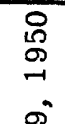 & ชิ & 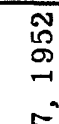 \\
\hline
\end{tabular}

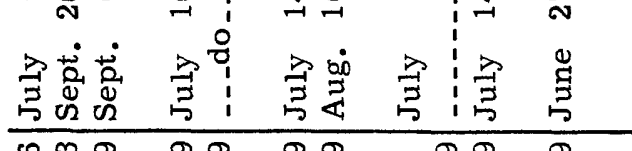

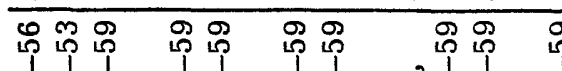

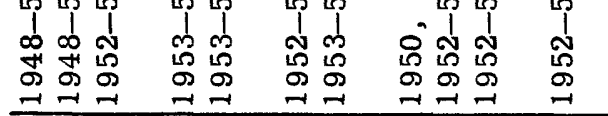

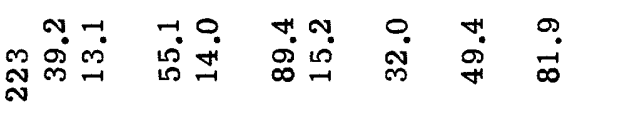

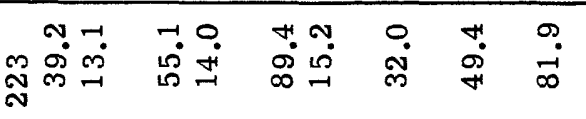

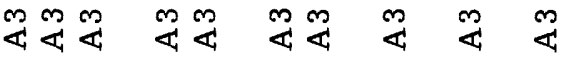

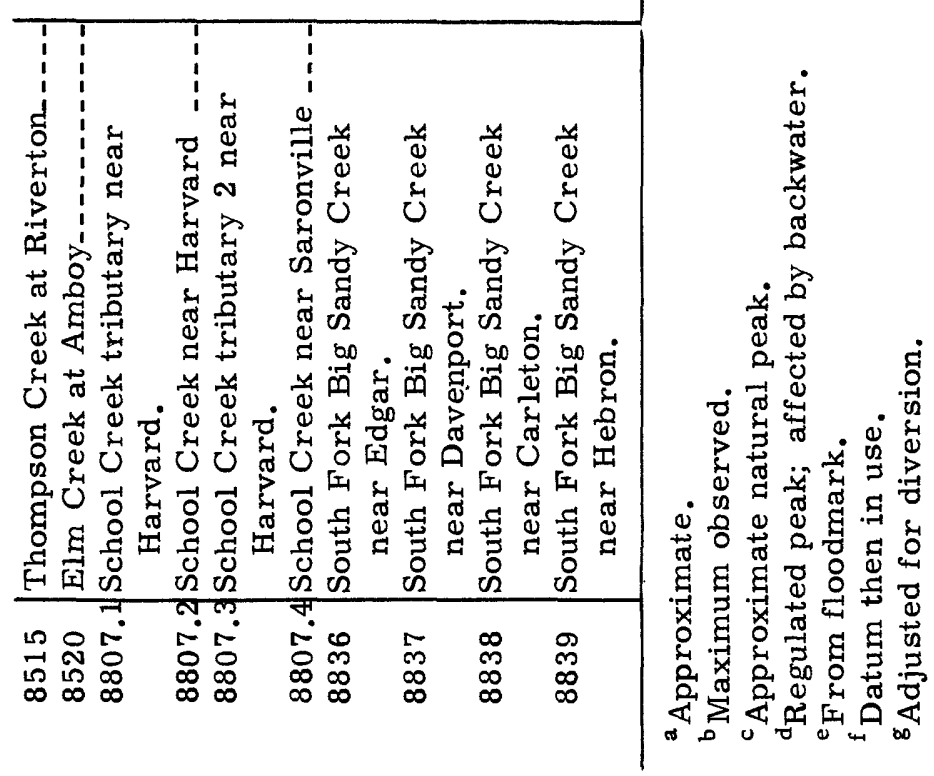




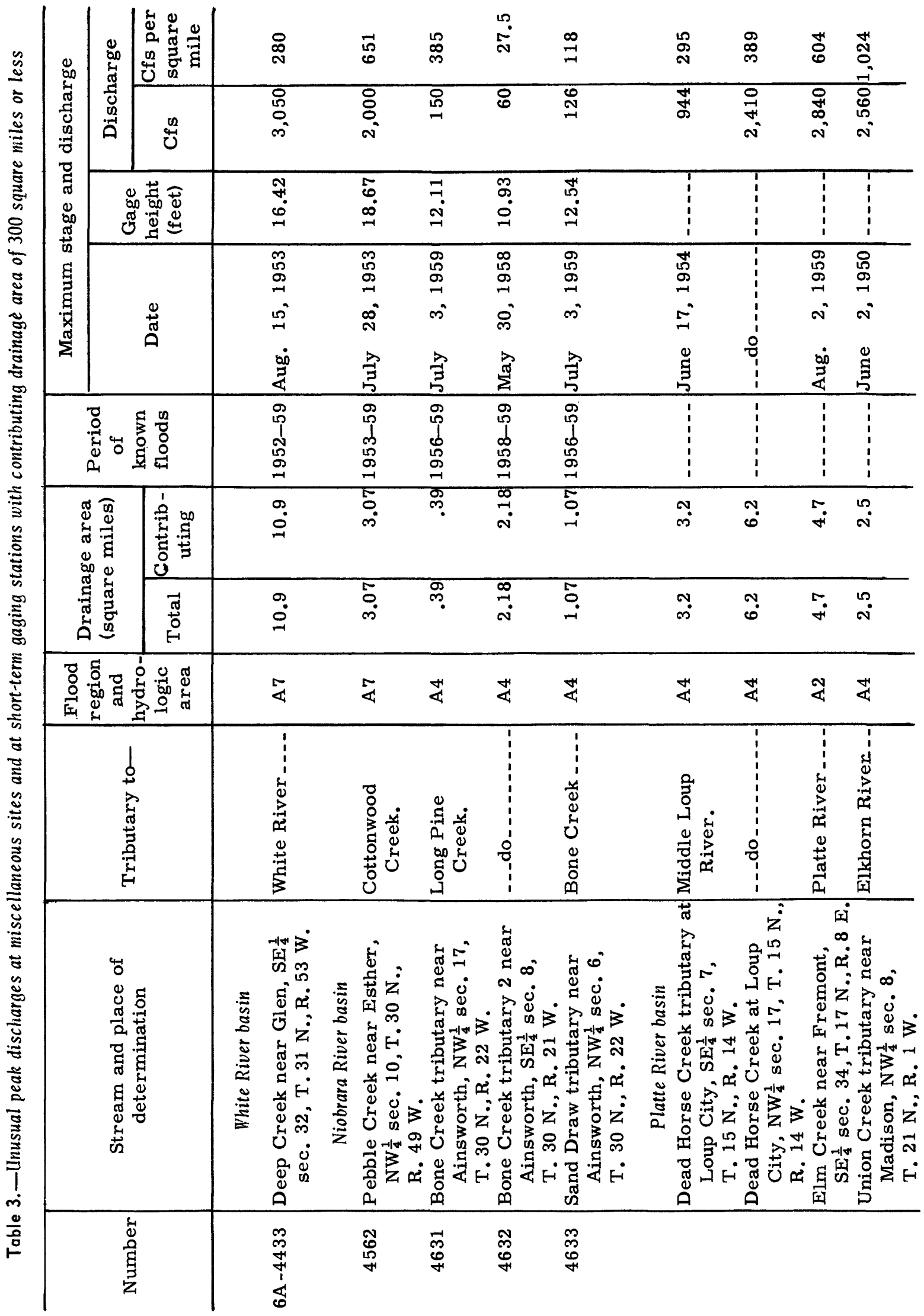




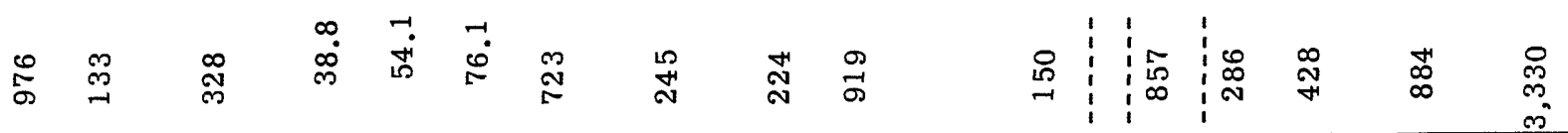

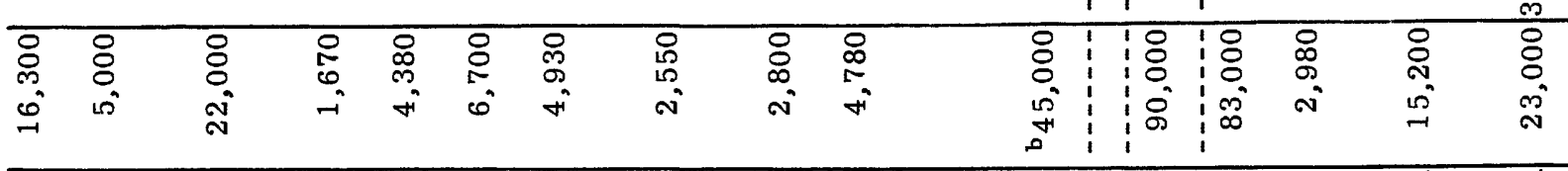

\begin{tabular}{|c|c|c|c|c|c|c|c|c|c|c|c|c|c|c|c|}
\hline $\begin{array}{l}1 \\
1 \\
1 \\
1 \\
\end{array}$ & $\begin{array}{l}1 \\
\vdots \\
1 \\
\vdots\end{array}$ & 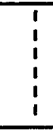 & $\begin{array}{l}0 \\
\stackrel{\leftrightarrow}{*} \\
\stackrel{-1}{-1}\end{array}$ & \begin{tabular}{l}
\multirow{0}{0}{} \\
$\stackrel{0}{0}$
\end{tabular} & 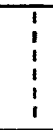 & $\begin{array}{c}1 \\
\vdots \\
\vdots \\
\vdots\end{array}$ & $\stackrel{\infty}{\stackrel{\infty}{\sim}}$ & $\begin{array}{l}\text { के } \\
\text { ‡. }\end{array}$ & i & 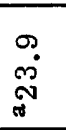 & $\begin{array}{rll} & \\
& & \\
& & \\
1 & & \\
1 & 1 & \\
\end{array}$ & & 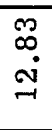 & i & $\begin{array}{l}i \\
\vdots \\
\vdots\end{array}$ \\
\hline \multirow[t]{2}{*}{ 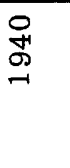 } & 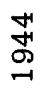 & $\underset{-~}{\stackrel{H}{*}}$ & 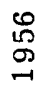 & $\begin{array}{l}\infty \\
1 \\
\stackrel{1}{-1}\end{array}$ & 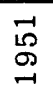 & 롱 & $\begin{array}{l}\infty \\
\stackrel{\infty}{10} \\
\stackrel{-1}{-1}\end{array}$ & 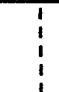 & $\begin{array}{l}\text { 今 } \\
\stackrel{0}{0} \\
\stackrel{-1}{-1}\end{array}$ & $\begin{array}{l}10 \\
\stackrel{10}{0} \\
\stackrel{-1}{-1}\end{array}$ & 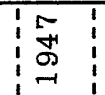 & Fั & $\begin{array}{l}\text { I } \\
\stackrel{2}{\circ} \\
\stackrel{-1}{-1}\end{array}$ & $\begin{array}{l}8 \\
\stackrel{10}{15} \\
\stackrel{-1}{-1}\end{array}$ & \\
\hline & $\stackrel{\infty}{\infty}$ & $\Rightarrow$ & $\stackrel{\infty}{\rightarrow}$ & $\stackrel{0}{\circ}$ & N & \pm & $\stackrel{0}{0}$ & $i$ & v & $-i$ & $i \vec{N}$ & $\vec{i}$ & $\stackrel{\circ}{\rightarrow}$ & $\infty$ & ! \\
\hline 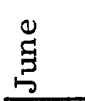 & 嵒 & $\stackrel{0}{\Xi}$ & $\stackrel{\dot{0}}{3}$ & $\underset{⿱ 乛}{3}$ & $\stackrel{0}{\Xi}$ & $\stackrel{0}{5}$ & $\frac{2}{3}$ & $\begin{array}{r}0 \\
1 \\
1 \\
\end{array}$ & $\dot{0}$ & $\stackrel{0}{\Xi}$ & $\begin{array}{ll}1 & 0 \\
1 & 5 \\
1 & \\
1 & \end{array}$ & $\underset{5}{5}$ & $\sum_{\Sigma}^{\infty}$ & $\frac{\overrightarrow{3}}{5}$ & $\begin{array}{r}0 \\
1 \\
1\end{array}$ \\
\hline \begin{tabular}{ll}
1 & 0 \\
& 0 \\
$\infty$ & $\stackrel{5}{\circ}$ \\
-1 & \multicolumn{1}{c}{}
\end{tabular} & $\begin{array}{l}i \\
i \\
i\end{array}$ & i & $\begin{array}{l}9 \\
10 \\
1 \\
0 \\
0 \\
0 \\
-1\end{array}$ & $\begin{array}{l}0 \\
10 \\
1 \\
0 \\
10 \\
0 \\
-1\end{array}$ & $\begin{array}{l}m \\
\text { 10 } \\
\text { j } \\
8 \\
8\end{array}$ & 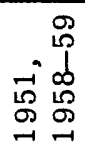 & $\begin{array}{l}0 \\
0 \\
1 \\
1 \\
10 \\
0 \\
01\end{array}$ & $\begin{array}{l}\text { o } \\
10 \\
0 \\
10 \\
\text { o } \\
-1\end{array}$ & 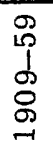 & $\overbrace{}^{\circ}$ & 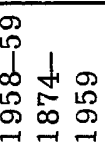 & $\begin{array}{l}1 \\
1 \\
1\end{array}$ & $\begin{array}{l}0 \\
10 \\
1 \\
\text { బิ } \\
0 \\
0 \\
-1\end{array}$ & $\begin{array}{l}1 \\
1 \\
1\end{array}$ & 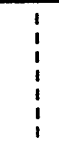 \\
\hline \begin{tabular}{l}
0 \\
\multirow{0}{0}{}
\end{tabular} & ז̊ & 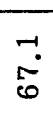 & $\stackrel{\infty}{+}$ & $\vec{\infty}$ & $\infty$ & $\begin{array}{l}\text { N } \\
\infty \\
0\end{array}$ & $\stackrel{\square}{\circ}$ & ڤ̊ำ & iั. & ஓ् & $\underset{-1}{\llcorner}$ & 옹 & $\begin{array}{l}5 \\
5 \\
0\end{array}$ & $\stackrel{\Upsilon}{\beth}$ & $\stackrel{9}{\circ}$ \\
\hline
\end{tabular}

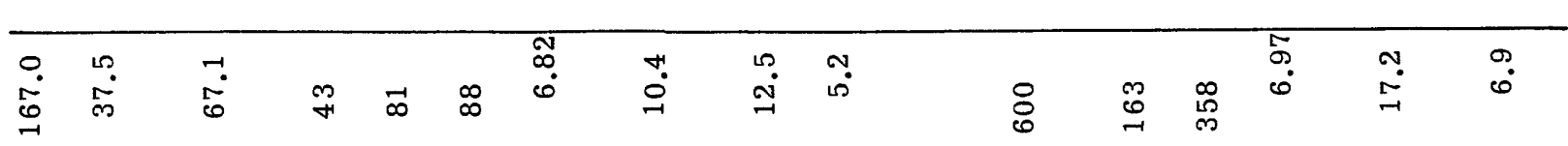

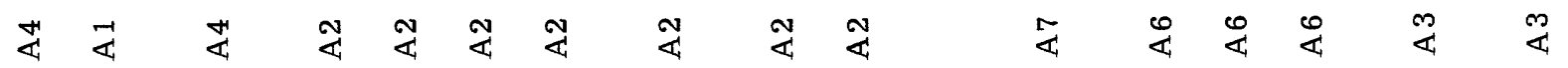

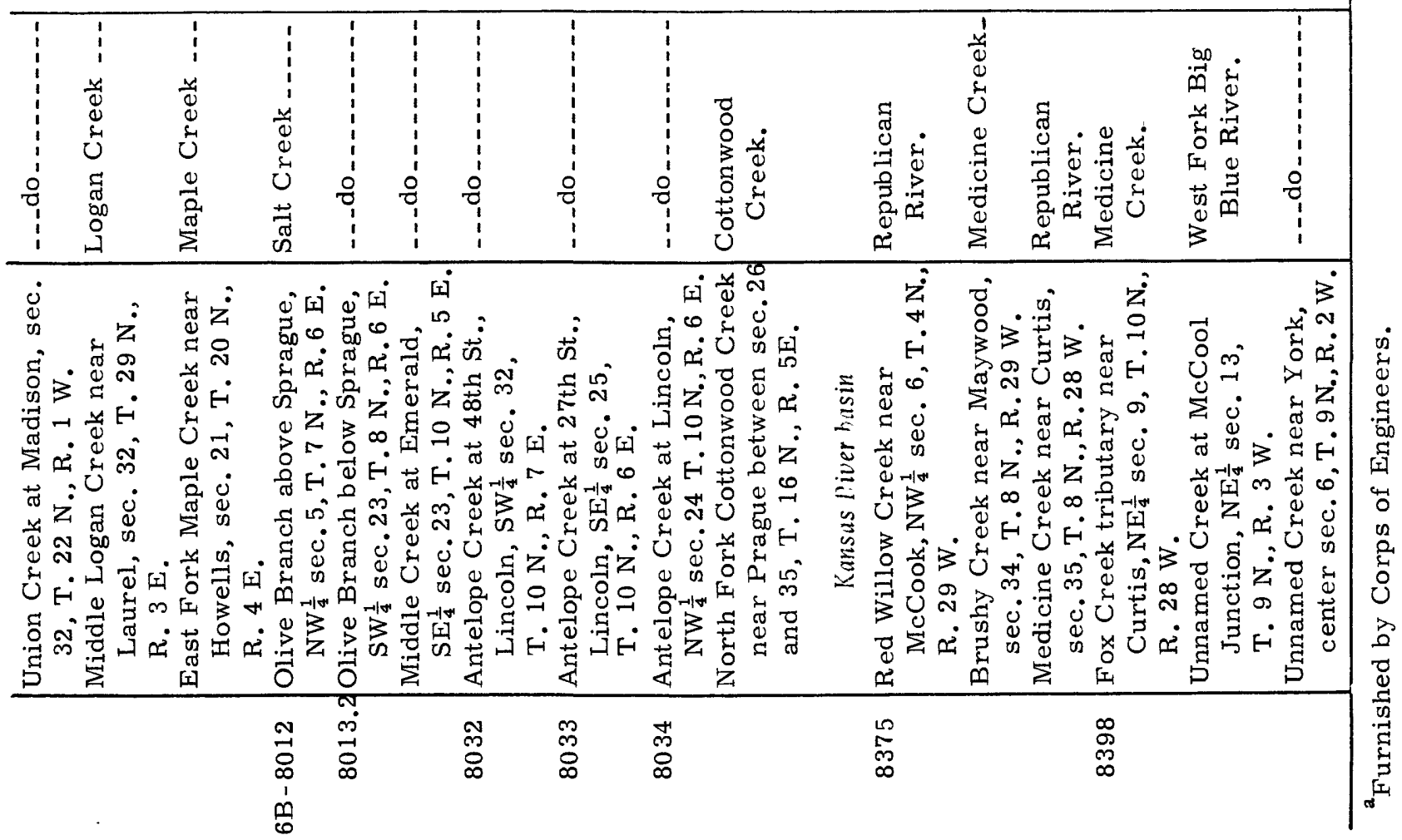



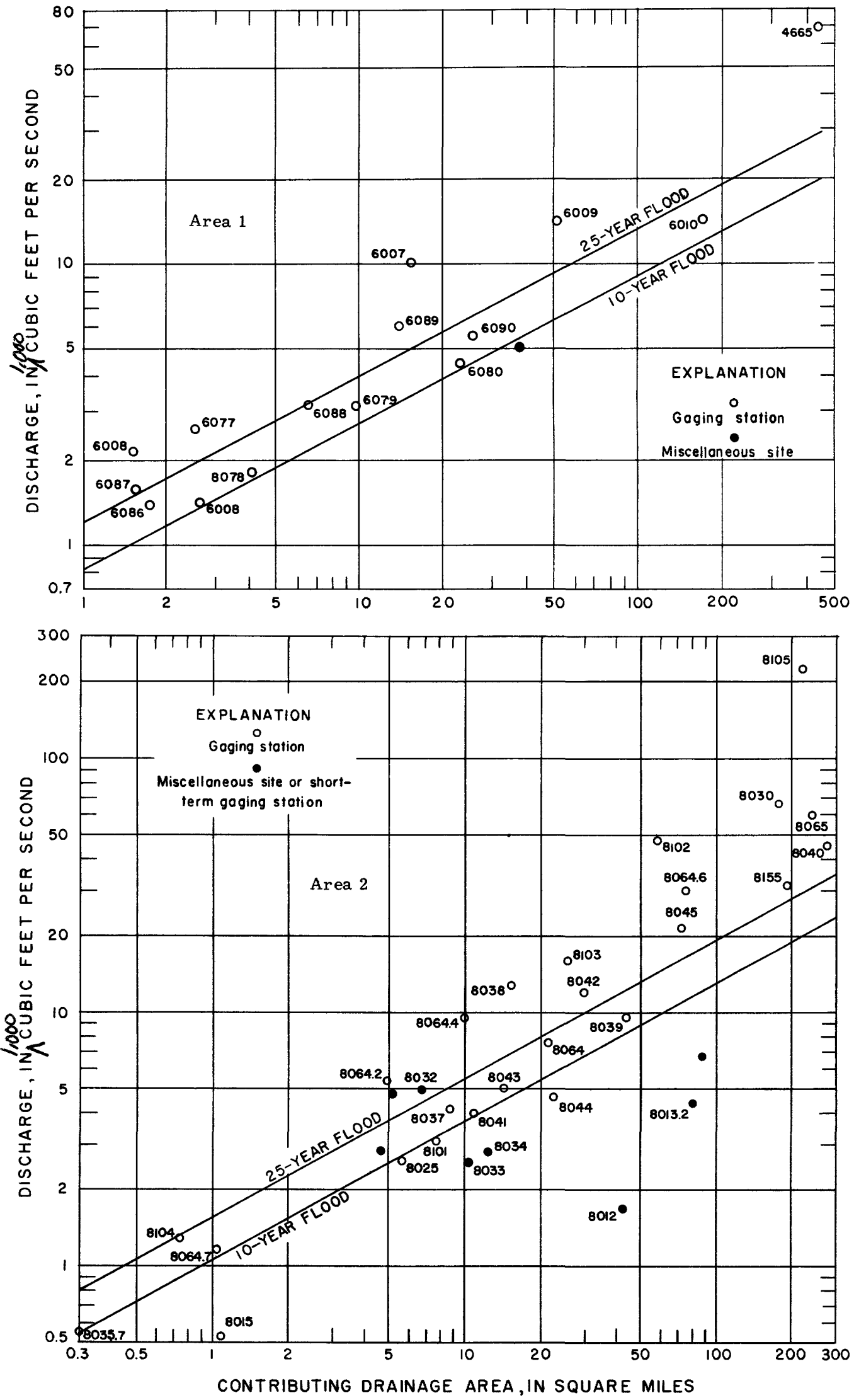

Figure 7. -Relation of maximum discharge to 10 and 25-year floods, region A, areas 1 and 2 . 

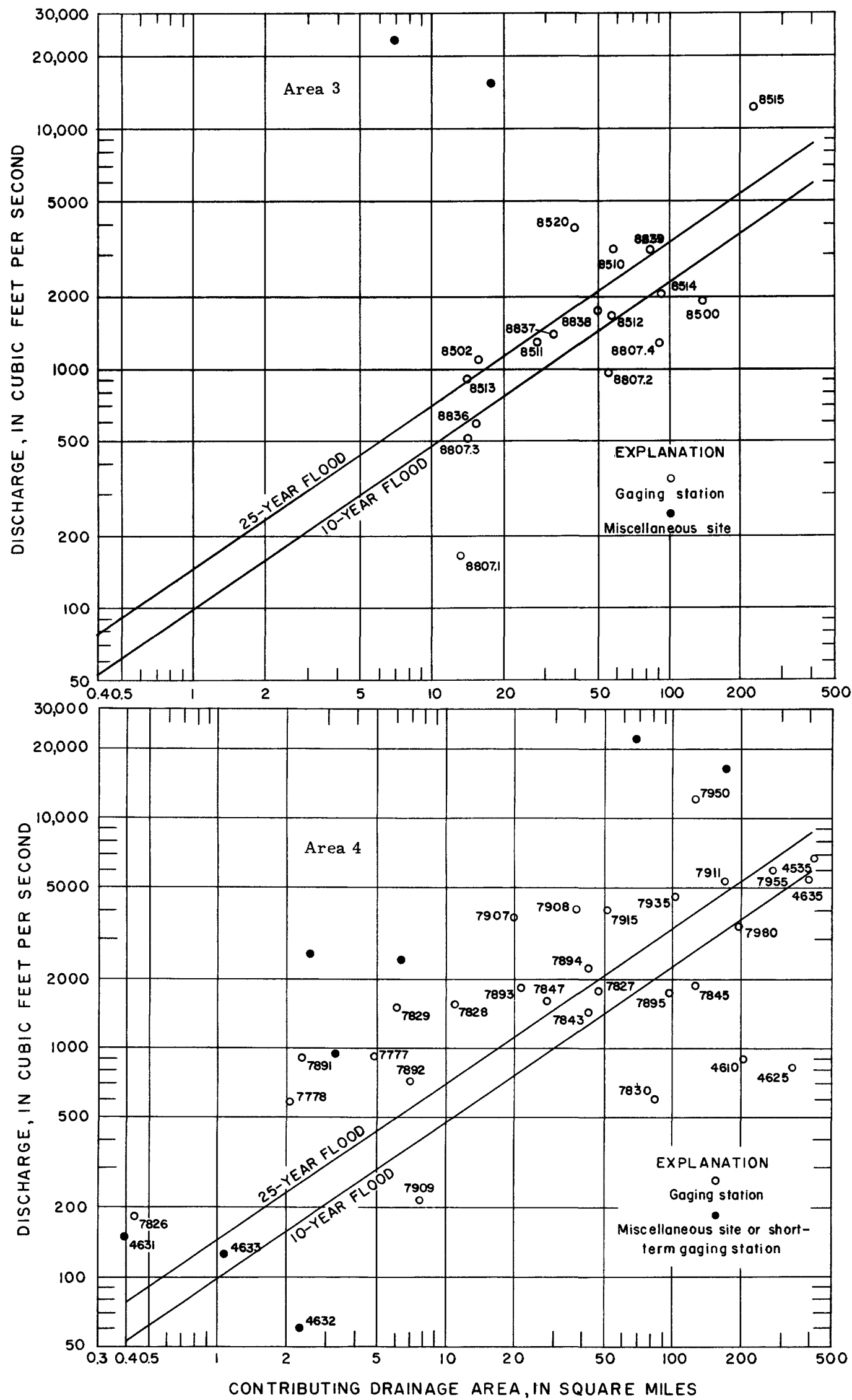

Figure 8.-Relation of maximum discharge to 10 and 25 -year floods, region $A$, areas 3 and 4 . 

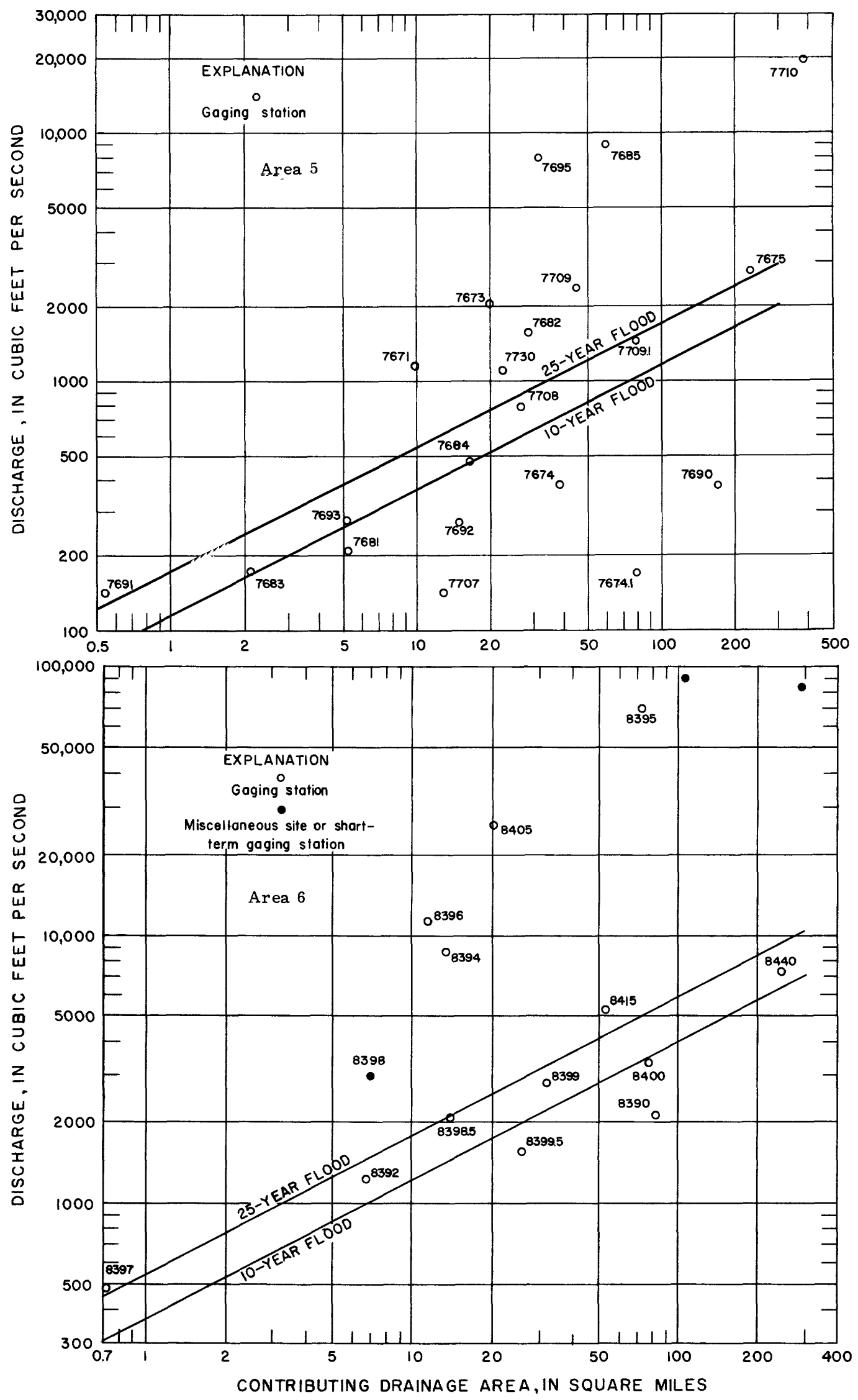

Figure 9.-Relation of maximum discharge to 10 and 25-year floods, region A, areas 5 and 6 . 


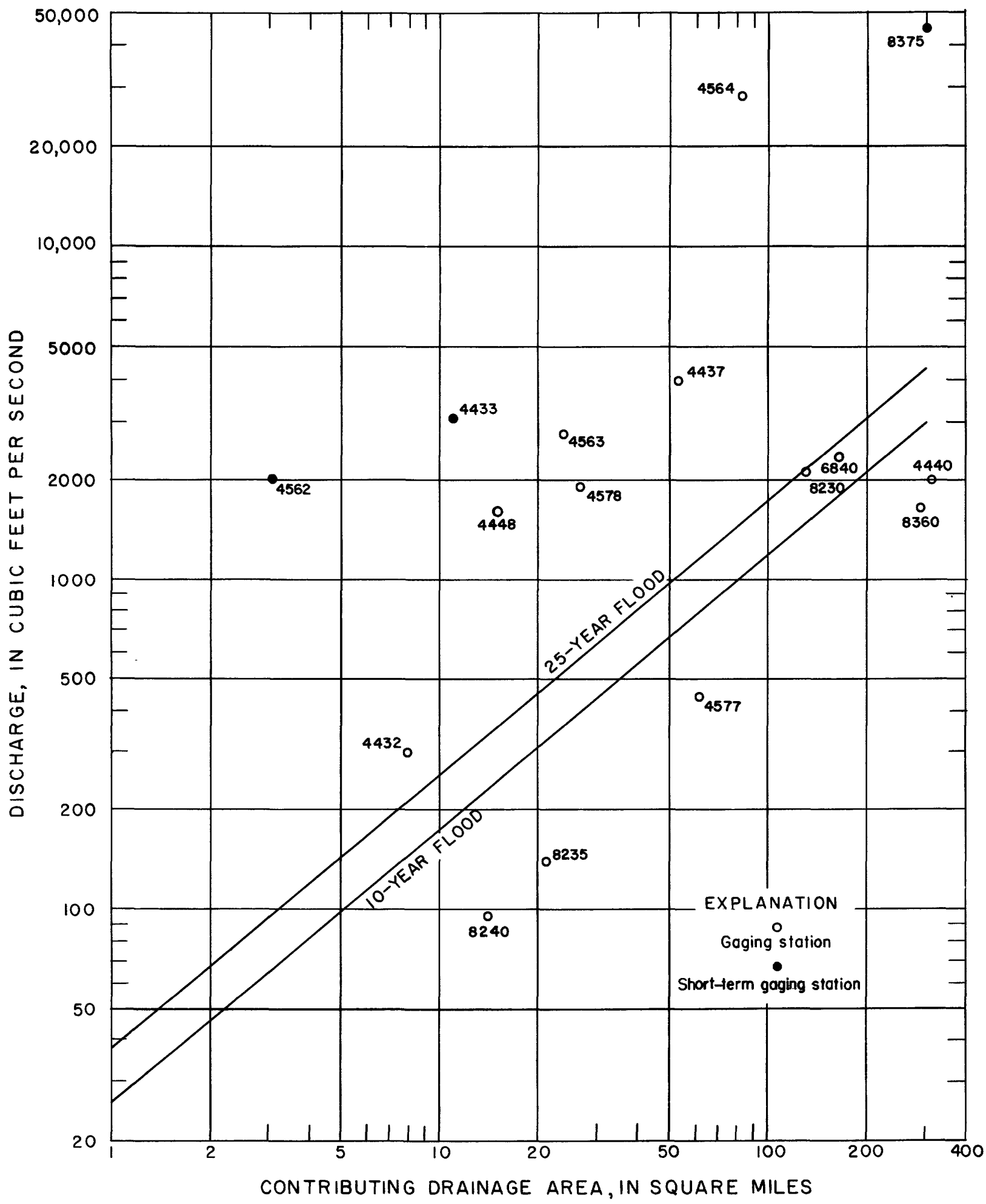

Figure 10. - Relation of maximum discharge to 10 and 25-year floods, region $A$, area 7. 

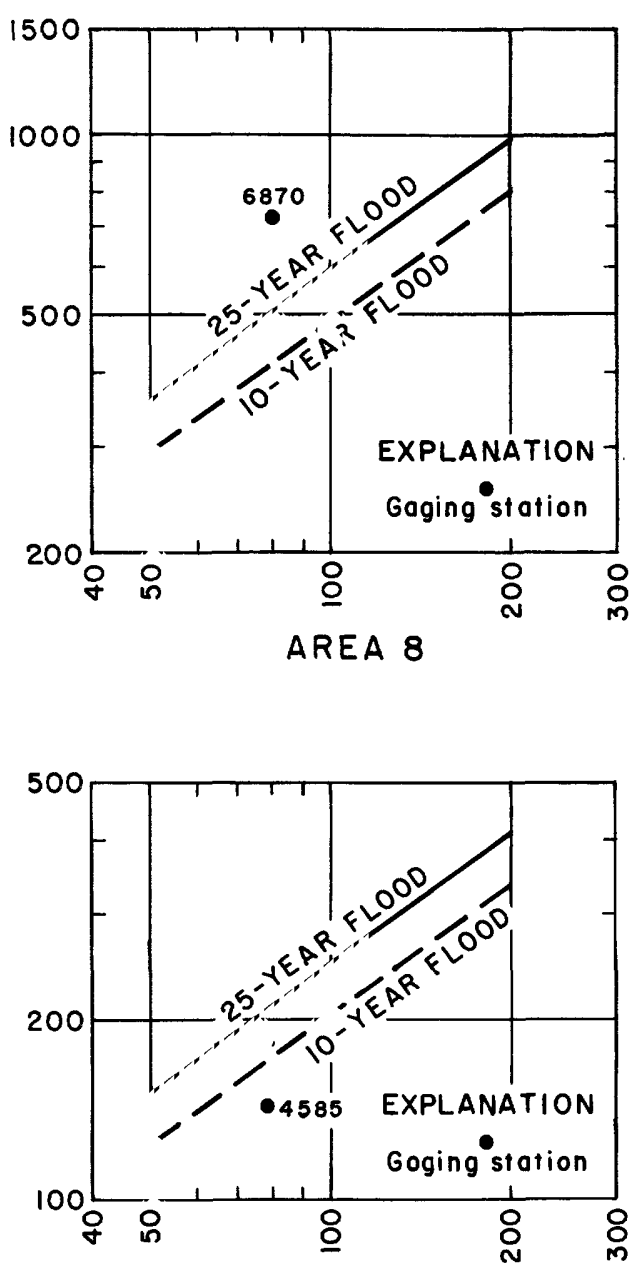

AREA 9

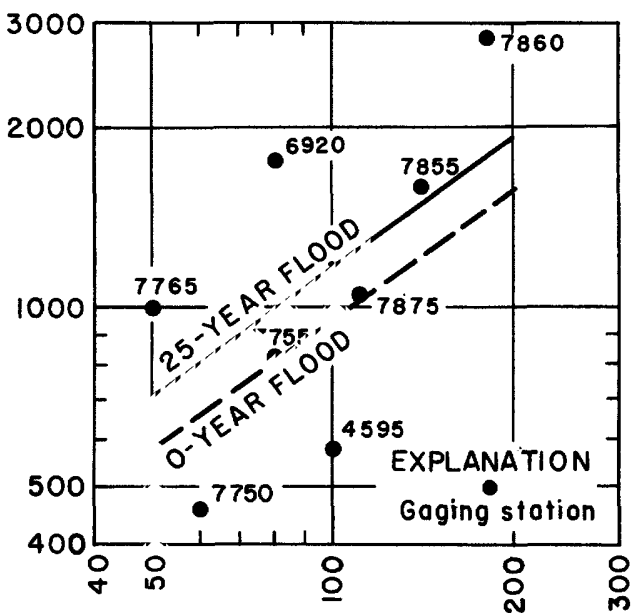

AREA 10

CONTRIBUTING DRAINAGE AREA IN SQUARE MILES

Figure 11. - Relation of maximum discharge to 10 and 25-year floods, region $B$, areas 8,9 and 10 .
SUMMARY

The accuracy of flood magnitudes for selected recurrence intervals obtained by methods outlined in this report is contingent upon the number of stations used, and the length of each record. When more data are obtained and, perhaps, improved methods of analysis are developed, better definition of the flood regime will be possible.

The curves presented are based on all available annual peak data through the 1959 water year on uncontrolled and unregulated streams having 300 square miles or less contributing drainage area, and 5 or more years record of annual peaks. The regional frequency curves cannot be extrapolated with confidence beyond 25 years. The drainage area-mean annual flood curves should not be extended beyond the limits shown.

The curves presented in this report should not be used on controlled and regulated streams.

\section{SELECTED REFERENCES}

Benson, M. A., 1960, Characteristics of frequency curves based on a theoretical 1,000year record, in Dalrymple, Tate, Flood-frequency analyses: U.S. Geol. Survey WaterSupply Paper 1543-A, p. 51-74.

Berwick, V. K., 1958, Floods in eastern Montana, magnitude and frequency: U.S. Geol. Survey open-file report.

Bigwood, B. L., and Thomas, M. P., 1955, A flood-flow formula for Connecticut: U.S. Geol. Survey Circ. 365.

Bodhaine, G. L., and Robinson, W. H., 1952, Floods in western Washington, frequency and magnitude in relation to drainage basin characteristics: U.S. Geol. Survey Circ. 191.

Carter, R. W., 1951, Floods in Georgia, frequency and magnitude: U.S. Geol. Survey Circ. 100.

Chow, Ven Te, 1950, Discussion of W. B. Lang bein's paper "Annual floods and the partialduration flood series:" Am. Geophys. Union Trans., v. 30, p. 939-941.

Condra, G. E., 1920, The soil resources of Nebraska: The Nebraska Conservation and Soil Survey, Univ. of Nebraska, Bull. 15, p. 1-76.

Cragwall, J.S., Jr., 1952, Floods in Louisiana, magnitude and frequency: Louisiana Dept. of Highways. 
Cross, W. P., and Webber, E. E., 1959, Flioods in Ohio, magnitude and frequency: Ohio Dept. of Natural Resources, Div. of Water Bull. 32.

Dalrymple, Tate, 1960, Flood-frequency analyses: U.S. Geol. Survey Water -Supply Paper 1543-A.

Darling, J. M., 1959, Floods in Maryland, mag nitude and frequency: U.S. Geol. Survey open-file report.

Ellis, D. W., and Edelen, G. W., Jr., 1960, Flood frequency, pt. 3 of Kansas streamflow characteristics: Kansas Water Resources Board Tech. Rept. 3.

Furness, L. W., 1955, Floods in Nebraska, magnitude and frequency: Nebraska Dept. of Roads and Irrigation, p. 2-3.

Green, A.R., and Hoggatt, R.E., 1960, Floods in Indiana, magnitude and frequency: U.S. Geol. Survey open-file report.

Gumbel, E. J., 1945, Floods estimated by probability method: Eng. News-Rec., v. 134, no. 24, p. 833-837.

Jenkins, D. S., and others, 1946, The origin, distribution, and airphoto identification of United States soils: U.S. Dept. of Commerce, Civil Aeronautics Adm., Tech. Devel. Rept. 52, pl. 1.

Langbein, W. B., 1949, Annual floods and the partial-duration series: Am. Geophys. Union Trans., v. 30, p. 879-881.

McCabe, J.A., 1958, Floods in Kentucky, magnitude and frequency: U.S. Geol. Survey open-file report.

McCabe, J. A., and Crosby, O. A., 1959, Floods in North and South Dakota, frequency and magnitude: U.S. Geol. Survey open-file report.

Mitchell, W. D., 1954, Floods in Illinois, mag nitude and frequency: Illinois Div, of Water ways, Dept. of Public Works and Buildings.
Nebraska State Planning Board, 1941, Water resources of Nebraska: p. 1-19.

Peirce, L. B., 1954, Magnitude and frequency of floods in Alabama: U.S. Geol. Survey Circ. 342.

Powell, R: W., 1943, A simple method of es timating flood frequencies: Civil Eng., vo 13, no. 2, p. 105-106.

Pride, R. W., 1958, Floods in Florida, magnitude and frequency: U.S. Geol. Survey open-file report.

Prior, C. H., 1949, Magnitude and frequency of floods in Minnesota: Minnesota Dept. Conserv., Div. of Waters Bull. 1.

Rantz, S. E., and Riggs, H. C., 1949, Magnitude and frequency of floods in the Columbia River basin, in Floods of May-June 1948 in Columbia River basin: U.S. Geol. Survey Water-Supply Paper 1080.

Riggs, H. C., 1955, Floods in North Carolina, magnitude and frequency: U.S. Geol. Survey open-file report.

Schwob, H. H., 1953, Iowa floods, magnitude and frequency: lowa Highway Research Board Bull. 1.

Searcy, J.K., 1955, Floods in Miszouri, magnitude and frequency: U.S. Geol. Survey Circ. 370.

Tice, R. H., 1958, Delaware River basin, flood frequency: U.S. Geol. Survey open-file report.

U.S. Geological. Survey, Water Resources Division, 1952, Floods in Youghiogheny and Kiskiminetas River basins, Pennsylvania and Maryland, frequency and magnitude: U.S. Geol. Survey Circ. 204. 